\title{
An Overview on the Conservative Management of Endometriosis from a Naturopathic Perspective: Phytochemicals and Medicinal Plants
}

\author{
Andreea Balan ${ }^{1}$, Marius Alexandru Moga ${ }^{1}$, Lorena Dima ${ }^{2}$, Catalina Georgeta Dinu ${ }^{3}$, \\ Carmen Constantina Martinescu ${ }^{2}$, Diana Elena Panait ${ }^{2, *}$, Claudia Alexandrina Irimie ${ }^{2}$ and \\ Costin Vlad Anastasiu ${ }^{1}$ (D)
}

Citation: Balan, A.; Moga, M.A.; Dima, L.; Dinu, C.G.; Martinescu, C.C.; Panait, D.E.; Irimie, C.A.; Anastasiu, C.V. An Overview on the Conservative Management of Endometriosis from a Naturopathic Perspective: Phytochemicals and Medicinal Plants. Plants 2021, 10, 587. https://doi.org/10.3390/ plants10030587

Academic Editor:

Rodica-Mihaela Dinicǎ

Received: 7 March 2021

Accepted: 18 March 2021

Published: 20 March 2021

Publisher's Note: MDPI stays neutral with regard to jurisdictional claims in published maps and institutional affiliations.

Copyright: (c) 2021 by the authors. Licensee MDPI, Basel, Switzerland. This article is an open access article distributed under the terms and conditions of the Creative Commons Attribution (CC BY) license (https:/ / creativecommons.org/licenses/by/ $4.0 /)$.
1 Department of Medical and Surgical Specialities, Faculty of Medicine, Transilvania University, 500019 Brasov, Romania; andreea.balan@unitbv.ro (A.B.); mogas@unitbv.ro (M.A.M.); costin.anastasiu@unitbv.ro (C.V.A.)

2 Department of Fundamental, Prophylactical and Clinical Disciplines, Faculty of Medicine, Transilvania University, 500019 Brasov, Romania; lorena.dima@unitbv.ro (L.D.); carmen.martinescu@unitbv.ro (C.C.M.); claudia.deliu@unitbv.ro (C.A.I.)

3 Department of Law, Faculty of Law, Transilvania University, 500019 Brasov, Romania; catalina.matei@unitbv.ro

* Correspondence: diana.panait@unitbv.ro; Tel.: +40-0268-412-185
Abstract: Background: Endometriosis is a chronic and debilitating disease, which affects millions of young women worldwide. Although medicine has incontestably evolved in the last years, there is no common ground regarding the early and accurate diagnosis of this condition, its pathogenic mechanisms, and curative treatment. Even though the spontaneous resolution of endometriosis is sometimes possible, recent reports suggested that it can be a progressive condition. It can associate chronic pelvic pain, vaginal bleeding, infertility, or malignant degenerescence. Conventional treatments could produce many side effects, and despite treatment, the symptoms may reappear. In recent years, experimental evidence suggested that plant-based medicine could exert beneficial effects on endometriosis and endometriosis-related symptoms. This study aims to highlight the pharmaceutical activity of phytochemicals and medicinal plants against endometriosis and to provide a source of information regarding the alternative treatment of this condition. Methods: For this review, we performed a research using PubMed, GoogleScholar, and CrossRef databases. We selected the articles published between January 2000 and July 2020, written in English. Results: We found 17 medicinal plants and 13 phytochemicals, which have demonstrated their beneficial effects against endometriosis. Several of their biological activities consist of antiangiogenic, anti-inflammatory effects, and oxidative-stress reduction. Conclusion: Medicinal herbs and their bioactive compounds exhibit antiangiogenic, antioxidant, sedative and pain-alleviating properties and the effects recorded until now encourage their use for the conservative management of endometriosis.

Keywords: endometriosis; traditional Chinese Medicine; medicinal herbs; nutraceuticals; phytochemicals

\section{Introduction}

Endometriosis is a chronic gynecological condition, which usually affects women at reproductive age and has an extremely rare occurrence after menopause [1,2]. The incidence is increasing worldwide, presently rising close to $15 \%$ [3]. Defined by the presence and proliferation of functional endometrial-like tissues in sites other than the uterus, it causes chronic pelvic pain that does not necessarily correlate with the depth or extent of tissue infiltration [4]. Other symptoms involve lumbar pain, reduced fertility or infertility, dysmenorrhea, dyspareunia, dysuria, and dyschezia [5]. Endometriotic lesions may be both endopelvic or extrapelvic. Endopelvic foci could be located into 
ovaries, fallopian tubes or uterosacral ligaments. Extrapelvic sites include the abdominal wall, gastrointestinal tract, urinary tract, and nasal mucosa. Some sources indicated that extrapelvic endometriosis is produced by the bone marrow-derived stem cells, which move across the peripheral circulation and generate endometriosis in obscure sites [6].

Endometriosis is considered a multi-factorial disorder of unclear etiology, induced by genetic, hormonal, and immunological factors. Several theories have been suggested in order to explain the ethiopathogenesis of endometriosis. The most accepted theory is Sampson's retrograde menstruation theory, which implies that endometriosis develops as a result of a retrograde flow of discarded endometrial debris through the fallopian tubes towards the peritoneal cavity during menstruation [7]. Interestingly, almost $76-90 \%$ of the women with permeable fallopian tubes present retrograde menstruation, but only a small amount of them develop endometriosis [8]. Studies on non-human primate subjects showed that endometriosis can be induced by placing curetted menstrual endometrium into the peritoneal cavity [9], with a positive result in up to $100 \%$ of animals after two successive rounds of inoculation [10]. Endometriotic lesions in primates were clinically and histologically identical with the lesions found in humans [11].

The epigenetic theory suggests that during organogenesis, Homeobox and Wingless family genes are fundamental for the development of urogenital tract structures. A dysregulation at the level of $\mathrm{Wnt} / \mathrm{b}$-catenin signaling pathway will result in an abnormal arrangement of the stem cells. Pro-inflammatory peritoneal habitat, immune alteration and the abnormal arrangement of the stem cells will evolve into endometriosis [3,12]. Additionally, miRNAs dysregulations were reported as trigger factors for a more aggressive proliferation and invasion of the endometrial cells in ectopic sites. Epigenetics has an indirect role in the differentiation of bone marrow-derived stem cells by regulating the steroid action and the inflammatory microenvironment. The interaction leads to the recruitment of bone marrow-derived stem cells, which are vastly affected by the epigenetic expression [13].

The diagnosis of endometriosis is frequently delayed, sometimes up to 7-9 years. This delay is due to the unspecific symptoms and to the difficulty of pronouncing a diagnosis, which is usually established after the histological exam of the surgically removed tissues. A delayed diagnosis and treatment results in chronic pain and infertility that leads to psychological distress, hence to a poor quality of life [14].

Endometriosis is very challenging to treat. The management of endometriosis could be surgical or conservative [15]. The most commonly used therapeutic agents are nonsteroidal anti-inflammatory drugs (NSAID) and hormonal medication for repressing the ovarian function, such as oral contraceptives, gonadotropin-releasing hormone (GnRH) agonists, selective progesterone receptor modulators, androgens, or aromatase inhibitors [16]. Aromatase inhibitors, GnRH antagonists, anti-tumor necrosis factor- $\alpha$ (TNF- $\alpha$ ), antiangiogenic factors and selective progesterone receptor modulators are the newest medical therapies for endometriosis [17]. These hormonal treatments have various side effects and usually they are not fully effective [18]. In addition to the drug therapy, the surgical resection is used in order to remove the detectable ectopic sites of endometriosis, leading to improved fertility, and complete or partial pain relief. However, the reoccurrence of the endometriotic lesions is still possible [19].

Natural alternative therapies consisting of medicinal plants and phytochemicals could offer new options for the management of endometriosis. Numerous natural products with different pharmaceutical effects have shown a reduction in the size of endometriotic lesions, lowered the pelvic adhesions, and improved pelvic pain and ovarian function [20]. Medicinal herbs and their bioactive compounds exhibit anti-angiogenic, anti-oxidative, sedative and pain-alleviating properties, and the beneficial effects recorded until now encourage their use for the management of endometriosis [21].

For centuries, Traditional Chinese Medicine (TCM) has attracted extensive attention for its ability to treat and alleviate a wide range of chronic diseases. Furthermore, TCM has significant advantages in treating various gynecological disorders including endometrio- 
sis [22]. Considering the complex pathogenesis of this dysfunction and the limited effects of the conventional treatments, Chinese medicines were used to treat the endometriotic lesions and to control endometriosis-related symptoms such as pelvic pain, dysmenorrhea, and abnormal uterine bleeding [20]. Considering the complexity of TCM, the differences in clinical experience and the lack of clinical studies, a depth research of the mechanisms of action of the herbs is required [23].

In this article, we focused on the studies regarding the pharmaceutical effects of medicinal plants and phytochemicals against endometriosis. Our main objective is to bring together all these studies in order to establish whether and through which mechanisms these natural remedies can relieve the symptomatology and can influence the progression of endometriotic lesions.

\section{Materials and Methods}

This study is a review of the last twenty years of English literature, regarding the alternative treatments of endometriosis. With an ongoing interest in the field of plant-based therapy for endometriosis, we aimed to address this topic given the high burden that this gynecological dysfunction possesses on public health. A long array of studies on the conventional medical treatment of endometriosis were conducted. However, plant-based therapies raised more and more attention for their pharmaceutical properties against this gynecological pathology and our objective was to bring together all the studies conducted on this topic. Our research included all the papers published during January 2000 and July 2020, related to herbal and phytochemicals therapy for endometriosis, and to their mechanisms of action. We used the following Medical Subject Headings (MeSH) keywords: "endometriosis", "Traditional Chinese Medicine", "medicinal plants", "nutraceuticals", and "phytochemicals". Two authors separately identified the relevant papers and selected them based on the following inclusion criteria: full-text original articles, written in English, conducted in vivo, in vitro or clinical trials on humans. The exclusion criteria were: papers written in other language than English, abstracts, and duplicate papers. A total number of 143 studies were selected and after the exclusion of duplicates, 75 studies fitted our area of interest and respected our criteria.

\section{Pathogenic Pathways of Endometriosis}

\subsection{Inflammatory Pathways in Endometriosis}

Endometriosis is a complex gynecological disorder resulted from the interaction of various hormonal, immunological, and genetic factors. It is especially characterized by chronic inflammation and increased angiogenesis [24]. The local inflammatory response represents the main pathway for the initiation and progression of the disease [25]. In healthy women, the peritoneal fluid contains almost $85 \%$ macrophages [26]. Many studies revealed that the peritoneal fluid of the affected women contains increased levels of immune cells and macrophages, leading to an increased secretion of prostaglandins, cytokines, growth factors, and angiogenic factors, such as TNF- $\alpha$, interleukin-1 (IL-1), interleukin-8 (IL-8), transforming growth factor beta (TGF- $\beta$ ), and interferon- $\gamma$ [27].

Prostaglandin E2 (PGE2) is an eicosanoid with various physiological and pathological functions that have been considered indispensable for the development of endometriosis. According to Wu et al. [28], PGE2 regulates cell proliferation, angiogenesis, immune suppression, and it represents a crucial point in the molecular mechanism of endometriosis [29]. PGE2 interacts with its receptors, known as EP1, EP2, EP3, and EP4, and acts on specific target cells through alternate or opposing intracellular pathways [30].

The inflammatory environment of this disease points out an increased production of estrogens. This event will raise the production of PGs through the activation of both Nuclear factor $\mathrm{kB}(\mathrm{NF}-\mathrm{kB})$ and cyclooxygenase-2 (COX-2) [31]. In ectopic endometrial areas, the levels of COX-2 are very increased. PGE2 increases the levels of COX-2 in both ectopic and eutopic endometrium. A paper of Banu et al. [32] highlighted the influence of COX-2 and PGE2 on the promotion of the migration and invasion of endometrial cells. 
Furthermore, the inhibition of COX-2 was able to decline the invasion of epithelial and stromal cells in endometriosis.

Eutopic endometrial cells are rich in NF-k subunits which activate during menstruation. The activation of these subunits in endometriotic cells in vitro increased the secretion of proinflammatory cytokines, IL-6, IL-8, ICAM-1, granulocyte-macrophage colonystimulating factor (GM-CSF), TNF- $\alpha$, macrophage migration inhibitory factor (MIF), and MCP-1 [33]. The inhibition of this molecule in nude mice with early-stage endometriosis decreased the proliferation of endometriotic cells and stimulated apoptosis in both stromal and epithelial cells [34]. The common point of view of the reaserchers is that in endometriosis, NF-kappa B represents the link between the inflammation process and the expression of aromatase. The activation of NF-kappa B subunits, followed by the translocation from the cytoplasm to cell nuclei, represents the first step to induce the inflammatory process [35]. Activated NF-kB will release IL-6, IL-8, IL-1, TNF- $\alpha$, and VEGF, leading to chronic inflammation.

Immune dysfunction characterized by hyperactive peritoneal macrophages with altered phagocytic ability represents another key-point in endometriosis development and progression. The phagocytic ability of macrophages is mediated by the secretion of matrix metalloproteinases (MMP). These are enzymes capable to destroy the organization of extracellular matrix, and the expression of several macrophages surface receptors. MMPs are also able to promote the dissolution of the cellular debris [36].

Different alterations of the MMPs activity are considered compelling factors in endometriosis development [37,38]. Most of the MMPs are secreted as dormant pro-enzymes, which later will be activated via proteolytic action. MMPs action is controlled by tissue inhibitors of metalloproteinases (TIMPs), and by the endogenous inhibitors [39]. Recent studies reported an increased expression of MMP-9, $-7,-3$, and -2 in patients with endometriosis [40,41]. Elevated levels of MMP-3 have been observed in animal models with induced endometriosis [42]. MMP-2, also known as gelatinase A, promotes tumoral cells migration though the degradation of collagen $\mathrm{X}, \mathrm{V}$, and IV, which represents an important structural part of the basement membrane [43]. The peritoneal fluid of endometriosis patients contains elevated levels of MMPs-2 comparing to healthy patients [44]. Additionally, the expression of MMP-2 in the peritoneal fluid of the affected women has been positively associated with the level of $17 \beta$-estradiol, and negatively associated with serum levels of progesterone [45].

Recent reports have pointed out the major role of reactive oxygen species (ROS) in endometriosis-related inflammation. In healthy individuals, there is a balance between ROS and antioxidants. When this balance bends toward ROS overproduction, oxidative stress increases, leading to the inflammatory process via the upregulation of various proinflammatory factors [46,47]. Hydroxyl radicals are considered to be the highest reactive free radical species [48]. They have the capacity to react with many cellular constituents such as amino acid residues, and also to attack the annular lipid shell, leading to lipid peroxidation [48,49]. The excessive production of ROS causes cellular damage and alters the function of the cells by controlling gene expression and proteins activity [50,51]. It has been demonstrated that ROS regulates the nuclear factor $\kappa \mathrm{B}(\mathrm{NF}-\mathrm{kB})$, which has been associated with endometriosis [52]. NF- $\mathrm{KB}$ promotes the expression of several genes that encode proinflammatory cytokines, adhesion molecules, angiogenic and growth factors, and cyclooxigenases $[25,52]$. This process leads to macrophages activation, endometrial cells proliferation, and increased adhesion and neovascularization [53]. The essential role of ROS in endometriosis consists of the positive regulation of transcription factors such as NF-kB and activator-protein 1 . These molecules regulate several genes involved in the cellular defense and in the expression of various proinflammatory cytokines, integrins and cadherins [54]. 


\subsection{Angiogenesis in Endometriosis}

Angiogenesis is a biological process, which consists of the formation of novel blood vessels, increased secretion of growth factors, dissolution of the extracellular matrix, multiplication, and agglutination of the endothelial cells in order to form new capillaries-like tubes [55].

VEGF is an angiogenic growth factor, usually highly expressed in tumors and endometriosis. This molecule increases the permeability of endothelial cells via two mechanisms: by enhancing the activity of vesicular-vacuolar organelles and by mitogen-activated protein (MAP) kinase signal transduction cascade, which targets the loose of adhering junctions between endothelial cells via rearrangement of adhesion complexes [56,57]. VEGF is a mitogen with high specificity for endothelial cells, which promotes their proliferation after binding its receptors: Flt-1/VEGFR-1, and Flk-1/KDR/VEGFR-2 [58].

VEGF exhibits angiogenic effects by inducing the expression of several molecules, such as $\alpha 1 \beta 1, \alpha 2 \beta 1$, and $\alpha v \beta 3$-integrins. These integrins regulate and promote cellular migration, proliferation, and matrix reorganization [59]. The transcription of VEGF mRNA, induced by hypoxia, is regulated through a mechanism, which consist of the binding of hypoxia-inducible factor 1 (HIF-1) to an HIF-1 binding site. This site is located in the promoter of VEGF. The transcription of VEGF mRNA is triggered by the activation of a stress-inducible PI3K/Akt pathway [59].

Fibroblast growth factors (FGFs) levels are increased in cancers and endometriosis, because these pathologies involve increased rates of angiogenesis. FGFs are important angiogenic molecules and endothelial cells survival factors. In addition, the expression of VEGF mRNA in endometriosis is up-regulated by high levels of bFGF. Overexpression of this molecule also up-regulates the expression of the proteins Bcl-XL and Bcl-2, with anti-apoptosis role, through the MEK/ERK signaling pathway [60].

In the last years, accumulating evidence showed that miRNAs target various angiogenic factors and protein kinases, and enhances neovascularization. In addition, these molecules can promote or inhibit angiogenesis in endometriotic lesions, through the modulation of pro-angiogenic signals (induced by VEGF) or anti-angiogenic signals (induced by thrombospondin-1 (TSP-1)). Moreover, miRNA targets receptor tyrosine kinases (RTKs) and hypoxia-inducible factor (HIF) and can crosstalk with ROS, influencing the angiogenesis process [61].

A study conducted in 2010 by Lee and coworkers [62] pointed out that the proangiogenic factor prokinetitsina-1 (PK-1) is highly expressed in ectopic foci of endometrial cells in comparison with eutopic cells.

\subsection{Apoptosis and Endometriosis}

Apoptosis is described as a physiological process, which induces serious cellular modifications, including pyknosis, nuclear fragmentation, blebbing of the plasma membrane, and cell shrinkage [63]. The apoptosis process ends with the production of small cellular fragments, known as apoptotic bodies. Apoptotic bodies are removed by phagocytosis, without enhancing a pro-inflammatory response [64]. In endometriosis, endometrial cells possess the ability to avoid apoptosis when they are localized in ectopic areas.

The apoptotic process is triggered by caspases, a group of protease enzymes, which determine the cleavage of C-terminal fragments into residues of aspartic acid upon activation [65]. The main class of caspases is represented by caspase- 9 homologues, also called "effector caspases" or "initiators". In animals, a complex composed by cytochromes, CED-4/Apaf-1 and procaspase-9, known as apoptosome, determine the activation of procaspase-9, which causes the effector caspase downstream cascade, and consequently, the degradation of the cells [66]. It is considered that apoptosis is triggered via extrinsic pathway, through the interaction between $\mathrm{TNF} \alpha$, Fas ligand (FasL/CD95L), transforming growth factor $\beta$ (TGF $\beta$ ), caspases and B cell lymphoma-2 (Bcl-2) family. Different studies pointed out that the endometrium of the endometriotic women expresses lower levels of 
pro-apoptotic factors (e.g., Bax), and increased levels of Bcl-2, an anti-apoptotic factor, in comparison with unaffected women [67].

Recent studies have shown that microRNA (miRNA) dysregulations play a role in endometriosis development [68]. The analysis of miR-183 revealed its involvement in the induction of apoptosis in human endometrial cells. A decreased expression of miR183 associated with endometriosis, leads to decreased apoptosis and, afterwards, to the advancement of the disease [69].

Existing data suggests that miR-191 suppresses TNF $\alpha$-induced cell death in ectopic endometrium from endometriosis patients. Additionally, miR-191 targets DAPK1, which represents a mediator of the cellular death. Thus, miR-191-DAPK1 pathway could not only be involved in the development of endometriotic lesions, but it could determine the malignant transformation of this condition [70].

In our opinion, knowing the molecular signaling pathways in endometriosis is essential for choosing the most appropriate therapeutic strategies to conquer this chronic enigmatic gynecological disease.

\section{Results}

\subsection{Phytochemicals for the Treatment of Endometriosis}

As we previous mentioned, the conventional treatment for endometriosis is still limited and associated with side effects. For this reason, an increasing number of women search for alternative options, such as phytotherapy, which is a promising strategy for the management of endometriosis. Phytochemicals such as flavonoids or phenolic acids proved their beneficial effects by exerting antioxidant, anti-inflammatory, immunomodulatory, and pro-apoptotic functions [71]. However, these treatments are still unconventional and their administration should be discussed in advance with a specialist.

\subsubsection{Apigenin}

Apigenin is the most active flavone which can be found in dietary sources such as chamomile tea, parsley, celery, oranges, celeriac, or wheat [72]. It possesses various biological activities such as antiproliferative, anti-angiogenic, anti-oxidative, and antiinflammatory properties. Adding apigenin to endometriotic stromal cells obtained after surgery, Suou et al. [73] observed that it attenuated the protein expression and TNF- $\alpha$ induced IL-8 gene expression. Two years later, same authors showed that apigenin can suppress cellular proliferation induced by TNF- $\alpha$. It attenuated chronic inflammation and mitogenic activity by suppressing PGE2 expression and by downregulating the NFkB pathway [74].

Park et al. [75] used human endometriosis cell lines (VK2/E6E7 and End1/E6E7) and observed that apigenin induced apoptosis and cell cycle arrest. Furthermore, it disrupted the mitochondrial membrane potential and increased cytosolic concentration of Bax and cytochrome c, which are pro-apoptotic proteins. A recent study [76] pointed out that apigenin is a potential phytoprogestin, a natural progesterone-like molecule capable to interact with the progesterone receptor (PR). It blocked the increase of endometrial cells height, suppressed genistein-induced proliferation of the endometrial cells and increased the expression of Hand2, a transcription factor stimulated by PR. In conclusion, apigenin is valuable for its antiproliferative, anti-angiogenic, anti-oxidative and anti-inflammatory effects, but it is also useful for its progesterone-like activity.

\subsection{2. $\beta$-Caryophyllene}

$\beta$-caryophyllene is a natural sesquiterpene, also known as phytocannabinoid. It can be found in essential oils of different medicinal or ornamental plants, spices or fruits. Food and Drug Administration approved this phytochemical as flavoring agent and taste enhancer [77]. Recently, it has been reported that $\beta$-caryophyllene can suppress tumoral growth and metastasis, and can induce apoptosis. These biological effects are possible through the suppression of PI3K/AKT/mTOR/S6K1 signaling pathways and the activation 
of ROS-mediated MAPKs. $\beta$-caryophyllene potentiates apoptosis and suppresses tumoral cells invasion via the activation of NF-kB. Furthermore, it has been demonstrated that $\beta$-caryophyllene suppresses the expression of Bcl-xL, IAP1, IAP2, Bcl-2, VEGF, MMP-9, COX-2, ICAM-1, and c-Myc [78].

According to several researchers $[79,80], \beta$-caryophyllene also exerts potent antiinflammatory activity in vivo, via decreasing the levels of TNF- $\alpha$, TLR-4, and IL-1ß. Using a rat model, Abbas et al. [80] showed that $\beta$-caryophyllene induced apoptosis in luminal epithelium of the ovarian endometriomas and in endothelial cells. In addition, this phytochemical decreased the growth of endometriotic foci by more than $52.5 \%$ in comparison to controls. $\beta$-caryophyllene is also able to modulate the level of oxidative stress. It restores antioxidant enzymes and represses glutathione (GSH) depletion and lipid peroxidation [81]

\subsubsection{Curcumin}

Curcumin is a hydrophobic polyphenol, also known as turmeric, derived from the rhizome of Curcuma longa. It possesses a wide range of pharmaceutical activities, such as anti-oxidative, anti-angiogenic, anti-proliferative, growth-suppressive, anti-inflammatory, and antimetastatic [82]. In endometriosis, curcumin reduced the number of endometriotic cells through the modulation of estrogen levels [83]. After the treatment with curcumin, the secretion of IL-1ß and NF- $\kappa B$ was significantly suppressed [84]. In addition, the release of TNF- $\alpha$ and TGF- 11 can be modulated by curcumin. It induces apoptosis via p53 and PI3K signaling pathways and through the up-regulation of the protein YAP/p53 [85].

This polyphenol exerts its anti-angiogenic function by inhibiting the VEGF/NF- $\kappa B$ signaling pathways and reducing the expression of VEGF [86]. In heterotopic endometrial tissue of rats, curcumin lowered VEGF expression and reduced the quantity of microvessels [87]. Furthermore, it proved its anti-oxidative potential by enhancing superoxide dismutase (SOD) and glutathione peroxidase (GPx) levels [86]. Lee et al. highlighted that curcumin decreases the invasiveness of tumoral cells by decreasing serum levels of MMP-2 and MMP-9, and altering the p53-E-cadherin pathway [88].

Sayantan et al. [42] showed that curcumin regresses endometriosis by inhibiting NF-kB translocation and MMP-3 expression. Moreover, it is able to induce apoptosis in ovarian endometriosis via cytochrome-c mediated mitochondrial pathway, independently of p53 protein.

It has been demonstrated that curcumin also inhibits the migration and invasion potential of tumoral cells. The synergistic treatment with curcumin and extracellular signalregulated kinase was leading to a significant decrease of invasive capabilities of tumoral endometrial cells, secondary to MMP-2 and MMP-9 reduction [89].

\subsubsection{Epigallocatechin-3-gallate}

Epigallocatechin-3-gallate (EGCG) is extracted from Camelia sinensis and is the most bioactive molecule in both green and black tea. It possesses antiangiogenic, pro-apoptotic and anti-proliferative effects [90] and due to its pharmaceutical effects, it could be used in the future in the management of endometriosis. No clinical trials on humans have been conducted until present. However, the results of the experiments realized on animals provided promising perspectives.

Xu et al. [91] reported that EGCG suppressed vascular endothelial growth factor C (VEGFC) and vascular endothelial growth factor receptor 2 (VEGFR2) in endometriotic foci. Furthermore, it significantly decreased the expression of VEGFC in endothelial cells and downregulated VEGFC/VEGFR2 signaling pathway in vivo, leading to decreased angiogenesis.

Endometriosis is characterized by fibrosis. A dense fibrous tissue induced by chronic inflammation surrounds the stroma and endometrial glands. Recent animal experiments pointed out that EGCG could prevent the fibrosis progression in endometriosis [92]. In vivo studies showed that the treatment with EGCG inhibited the proliferation, migration and in- 
vasion of endometriotic cells. Moreover, it inhibited TGF- $\beta 1$-stimulated activation of MAPK and Smad signaling pathways and the expression of miRNA TGF- $\beta 1$-dependent [92].

Pro-EGCG is a derivative of EGCG obtained by acetylation, which showed more potent anti-angiogenic effects that EGCG in mice models. It also possesses a better bioavailability in vivo in comparison with EGCG. Both EGCG and pro-EGCG inhibit the expression of VEGF and VEGFR activity, being valuable anti-angiogenic agents. Furthermore, they exert anti-oxidant activity in vitro and in vivo [93]. EGCG decreased the oxidative stress by activating the ERK1/2 and the p38 MAPK signaling pathways. The consequence was the up-regulation of $\mathrm{Nrf} 2 / \mathrm{HO}-1$ and the suppression of MAPK pathway.

In plasma, EGCG reduced the level of pro-inflammatory cytokines IL-17, IL-22 and IL-23. In addition, the level of tumor necrosis factor alpha (TNF- $\alpha$ ), IL-18, CD18, CD11s, and miRNA was decreased by EGCG administration [94,95]. EGCG is also able to promote apoptosis in endometriotic cells. Huang et al. [96] showed that EGCG promoted apoptosis in vitro by increasing the levels of caspase- 3 and using STAT3 and P53/Bcl-2 signaling pathways. Moreover, it suppressed the migration and invasion of tumoral cells by inducing the down-regulation of MMP-2 and MMP-9 [97].

\subsubsection{Genistein}

Genistein is an isoflavone isolated from soy. It possesses strong phytoestrogenic effects and both in vivo and in vitro studies have reported its efficiency for the management of endometriosis [4]. This molecule was reported to decrease the surface of the endometriotic implants and the histopathologic score through anti-angiogenic and anti-proliferative mechanisms [98]. Genistein exerts its anti-angiogenic effects by reducing the activity of PTK and MAPK, and by inhibiting HIF-1 and VEGF gene expression [99]. It induces programmed cellular death by suppressing Notch1/NF-kB /slug/E-cadherin pathway and by inducing G0/G1cell cycle arrest [100].

Genistein is also known for its antioxidant activity. The mechanism consist of the upregulation of Nrf2 and HO-1, and activation of Akt [101]. In addition, genistein was reported to decrease the expression of a wide range of pro-inflammatory factors, such as COX2, IL-6, TNF- $\alpha$, NF-kB, and IL-1ß [102].

In order to sustain the potential of genistein as phytoestrogen, Cotroneo et al. [103] attached uterine tissue to intestinal mesentery of Dawley rats. They observed that injections of genistein reduced uterine ER- $\alpha$, while pharmacologic injections of genistein significantly increased PR(B). They concluded that pharmacologically and not dietary genistein administration supported surgically induced endometriosis in ovariectomized rats and this molecule is a strong estrogen agonist.

\subsubsection{Luteolin and Chrysin}

Luteolin is a flavonoid that belongs to flavones group, along with chrysin and apigenin. It can be extracted from carrots, broccoli, green pepper, chamomile tea, or parsley [104] and it possesses antiproliferative and anti-inflammatory effects. Luteolin inhibited cell proliferation by inducing cell cycle arrest and DNA fragmentation in VK2/E6E7 (vaginal mucosa-derived epithelial endometriotic cells) and End1/E6E7 (endocervix-derived endometriotic cells) endometriotic cells. In endometriosis mice, intraperitoneally injected with luteolin, a significant reduction of the lesions size was reported. Furthermore, luteolin suppresses endometriosis progression by downregulation of the MAPK and PI3K/AKT signal proteins [105].

Luteolin can be considered a potent endocrine disruptor, which display progesterone antagonist activity. It possesses strong estrogen agonist activity and can modulate the growth of estrogen-dependent cells and tissues [106].

Chrysin is a natural flavone, especially derived from bee products such as propolis, honeycomb or honey. It can also be extracted from passion flowers and chamomile [107]. There is a small amount of studies conducted in order to elucidate the biological mechanism of chrysin on endometriosis. Ryu et al. [108] showed that chrysin exerted pro-apoptotic 
effects on End1/E6E7 and VK2/E6E7 endometriotic cells. Furthermore, it inhibited the proliferation of the cells. The programmed cell death was induced by increasing intracytosolic level of reactive oxygen species. Moreover, chrysin downregulated PI3K/AKT signaling pathway in a dose-dependent manner.

\subsubsection{Myricetin}

Myricetin is a natural compound included in the flavonols group. It is a plant-derived $\alpha$-glucosidase and $\alpha$-amylase inhibitor, with strong antioxidant activity [109]. It has been reported to be very efficient for relieving type 2 diabetes mellitus associated symptoms [109]. In a recent study, Park et al. [110] reported for the first time the antiproliferative effects of myricetin in endometriosis. They demonstrated that this compound inhibits cell cycle progression and cellular proliferation of human End1/E6E7 and VK2/E6E7 cells. In addition, myricetin leads to apoptosis by inducing the loss of mitochondrial membrane potential and ROS accumulation. In mouse model, this flavonol regressed the size of endometriotic foci by inhibiting Ccne1, and decreased the activation of AKT and ERK1/2 proteins. Considering these findings, myricetin could be a promising molecule for the management of endometriosis, but further research are urgently necessary in order to better describe the mechanisms of action against this gynecological condition.

\subsubsection{Naringenin}

Naringenin is included in the flavanones group and can be found in citrus and grapes. Its pharmaceutical effects consist of anti-inflammatory, antimutagenic, and anticancer properties [111]. Furthermore, it has been reported that naringenin induces apoptosis in various cellular lines, but unfortunately it has poor bioavailability and low aqueous solubility [112]. Naringenin inhibits cells proliferation and exerts pro-apoptotic effects in human endometriosis cells, through the depolarization of mitochondrial membrane potential. Moreover, naringenin is able to increase intracellular levels of ROS [113].

Naringenin ameliorated the expression of VEGF, reduced the volume of the endometriosis lesions and decreased serum levels of TNF- $\alpha$ in rats after 21 days of administration. In addition, naringenin reduced the expression of MMP-2 and MMP-9 in in vitro cells culture, by inhibiting the invasion of these cells [114].

\subsubsection{Puerarin}

Puerarin is an isoflavone with phytoestrogenic potential, which can be found in the roots of Pueraria spp. In rat models with endometriosis, was performed oral gavage with puerarin, and the results were evaluated four weeks after the administration. The weight of the ectopic endometrial tissue and the estrogen levels were significantly decreased in the study group in comparison to controls. These pieces of evidence demonstrated that puerarin is able to suppress the development and growth of endometriosis [115].

Wang et al. [116] have demonstrated that puerarin is able to suppress the vascularization and invasion of estrogen-stimulated endometriotic tissues. E2 increases MMP-9 and decreased TIMP-1 accumulation, leading to an increased invasiveness of endometriotic cells. Puerarin efficiently reversed these effects and, in addition, it degreased the levels of VEGF and ICAM-1, proving its anti-inflammatory and anti-angiogenic activities. Another study from the year 2012 [117] pointed out that puerarin significantly decreased the proliferation of endometriotic cells induced by 17ß-estradiol. The mechanism consisted of the downregulation of Cyclin D1, Cox-2, Cyp19, and by the abrogation of ERK pathway phosphorylation. Moreover, puerarin has been reported to downregulate mTOR signalling pathways, NF-kB signalling pathways, $\mathrm{BCl}-2$ and $\mathrm{PI} 3 \mathrm{~K}$ proteins, and to increase the activity of c- Jun $\mathrm{N}$ terminal kinase, miR-16, and extracellular signal-regulated kinase by $50 \%$. All these mechanisms lead to decreased cell proliferation and increased programmed cellular death [118], which transform puerarin into a promising therapeutic agent for the management of endometriosis. 


\subsubsection{Quercetin}

Flavonols is a class of flavonoids, which is widely distributed in various food sources such as apples, berries, broccoli, red grapes, onions, tea, and seeds [119]. Quercetin is a flavonol, which inhibits the cellular growth of cancer cell lines and induces antiproliferative effects in endometriotic cells, both in vivo and in vitro. Scambia et al. [120] showed that quercetin produced a dose-dependent inhibition of endometriotic cells. Zhang et al. evaluated the effects of quercetin on endometriosis rats. They observed that the size of endometriosis foci significantly decreased, along with a significant reduction of VEGF and heat shock protein 70 (HSP70) expression [121].

Furthermore, quercetin decreased the expression of PR and estrogen receptors (ER) $\alpha$ and $\beta$ in hypothalamus, pituitary gland, and endometrium of the endometriosis rats. In these conditions, quercetin could be considered an antiestrogen and progesterone molecule [122].

\subsubsection{Resveratrol}

Resveratrol is a natural phytoalexin, included in the family of stilbenes $[35,123]$. Various plants synthesize it in the presence of ultraviolet radiations. Wine, grapes, stilbenes, and berries represent the most common sources of resveratrol [124]. Resveratrol possesses various beneficial therapeutic effects, such as anti-inflammatory, anti-angiogenic, antioxidative and anti-neoplastic properties [125].

Resveratrol exerted its anti-inflammatory effects through the down-regulation of pro-inflammatory cytokines, and inhibition of COX-2 and prostaglandin expression [126]. In addition, it lowered the expression of ICAM1, suppressed MCP1, and inhibited NFKB/TLR-4 p65/MAPKs signaling cascade [127]. The suppression of COX-2 and aromatase in ectopic endometrial areas seems to be essential for the alleviation of endometriosisrelated chronic pelvic pain. In addition to this ability possessed by resveratrol, it can also block SIRT 1 and TGF-beta genes [128].

Resveratrol also possesses anti-angiogenic effects, manifested via GSK3beta/betacatenin/TCF-dependent pathway downregulation and VEFG inhibition [129]. Furthermore, this phytochemical is a potent antioxidant. Increased production of free oxygen radicals and low levels of glutathione peroxidase (GSH-Px) and SOD characterize endometriosis. After the supplementation with resveratrol, it was reported that the increased peritoneal levels of free oxygen radicals were suppressed [130]. Moreover, resveratrol attenuated the oxidative stress via activating Nrf2/HO-1 pathway and decreasing the levels of HO-1, catalase (CAT), SOD, and GPx [131,132].

\subsubsection{Xanthohumol}

Xanthohumol is a bioactive molecule contained by the female inflorescence of Humulus lupulus L., which has been widely used in plant-based medicine due to its beneficial activities. Beer is the most important dietary source of xanthohumol [133]. Due to its antiinflammatory, anti-proliferative, and anti-angiogenic properties, this prenylated flavonoid is known as a cancer chemopreventive agent. Rudzitis-Auth et al. [134] have reported that xanthohumol decreased the size of peritoneal ectopic endometrial tissue areas in mice, and reduced the level of phosphoinositide 3-kinase protein. Moreover, this molecule selectively lowered the density of microvessels from the endometriotic foci, without affecting uterine or ovarian vascularization. The anti-angiogenic function of xanthohumol was exerted via AKT/ NF- $\mathrm{kB}$ inhibition [135]. Furthermore, it has been reported that xanthohumol is able to modulate the inflammatory response, by suppressing the gene expression of proinflammatory molecules, such as IL-1, IL-6, MCP-1, and ICAM-1 [136].

Figure 1 is a schematic representation of the main mechanisms of action of these phytochemicals against endometriosis. 


\subsection{Medicinal Plants for the Treatment of Endometriosis}

\subsubsection{Angelica sinensis (Danggui)}

A. sinensis is a Chinese herbal medicine used for centuries for its anti-inflammatory, antioxidative, immunomodulatory, and antitumoral effects. In gynecology it has been used to treat menstrual disorders, such as dysmenorrhea or amenorrhea [137]. Over 70 bioactive molecules have been isolated from $A$. sinensis, such as phenols, amino acids, essential oils, carbohydrates, organic acids and vitamins [138], but the major constituents remain polysaccharides [139].

Xiong et al. [140] investigated the effects of $A$. sinensis on human endometriotic cells and rats. They observed that $A$. sinensis extracts significantly decreased inflammation both in vivo and in vitro. After the treatment, the peritoneal levels of TNF- $\alpha$ and IL-18 registered significantly lower values and CA-125 decreased. Moreover, it suppressed the expression of MMP-2 and MMP-9.

\subsubsection{Achillea biebersteinii (Yarrow)}

A. biebersteinii belongs to the family of Asteraceae, and in Turkish folk medicine it has been widely used for its emmenagogue potential [141]. The aerial parts of Achillea genus medicinal plants contain many biological active compounds such as flavonoids, monoterpenes, and sesquiterpenes [142], known for their beneficial effects consisting of anti-inflammatory, analgesic and antiseptic activities.

Demirel et al. [143] reported that $A$. biebersteinii reduced the volume of ectopic endometrial tissue areas and inhibited the developments of pelvic adhesions. After the administration of $A$. biebersteinii extracts, the levels of IL-6, VEGF, and TNF- $\alpha$ significantly decreased. In combination with Foeniculum vulgare, Peganum harmala, Nigella sativa, and Curcumin cyminum, this medicinal herb exerted strong effects against endometriosis-related dysmenorrhea. Furthermore, ethanol extracts of $A$. biebersteinii have been reported to possess strong antioxidant activity [144], and methanolic flower extract showed antinociceptive effects in mouse pain models, mediated by the cholinergic receptor [145].

\subsubsection{Artemisia princeps}

A. princeps belongs to the family Asteraceae, and its leaves have been used from years for the management of dysmenorrhea, infertility, and other endometriosis-related complaints. This medicinal plant contains a wide range of bioactive compounds such as flavonoids, terpenoids, sterolic acids, and coumarins [146]. It has been reported to have antitumor, antioxidant, antispasmodic, antihemorrhagic, and antiulcerogenic effects [4].

Kim et al. [147] used human endometriotic cells and reported that $A$. princeps leaf extract induced apoptosis in vitro. Pro-apoptotic mechanism consisted of the regulation of p38 and NF-kB pathways. In addition, A. princeps extracts inhibited the expression of Bcl-2, Bcl-xL, XIAP, caspase 3, caspase 8, and caspase 9 in a dose-dependent manner.

Another study [148] reported antiproliferative activity of eupatilin, a naturally flavonoid extracted from A. princeps, against tumor endometrial cells. This compound inhibited endometrial cells growth via G2/M phase cell cycle arrest, and up-regulated p21 protein, by the inhibition of mutant p53. A. princeps leaf extract also inhibited the proliferation of T lymphocyte and the secretion of IFN- $\gamma$ and IL-2. Ethanolic extract of this medicinal herb lowered the serum levels of TNF- $\alpha$, ICAM-1, IL-1B, and VCAM-1, according to Han et al. [149].

Jaceosidin is a natural flavone, which can be found in A. princeps. Kim et al. [150] pointed out that jaceosidin possesses antioxidative and anti-inflammatory activity. It suppressed $\mathrm{RO}$, nitric oxide (NO), and NF-kB and lowered the expression of nitric oxide synthase (iNOS) in lipopolysaccharide (LPS)-induced macrophages.

\subsubsection{Allium satioum}

A. sativum also known as garlic, is part of the Liliaceae family, and it is one of the most commonly used plants, with various pharmacological properties. Using human 
endometrial stromal cells, Kim et al. [151] showed that hexane extract of aged black garlic reduced cellular proliferation through the reduction of VCAM-1 and ICAM-1 expression. Further, pro-apoptotic activity of A. sativum was confirmed via caspase- 3 increased activity and by Bax: $\mathrm{Bcl}-2$ increased ratio.

Xiao et al. [152] demonstrated for the first time that diallyl trisulfide, a constituent of garlic, is able to inhibit angiogenesis in human endothelial cells. It suppressed the formation of novel capillaries, decreased the secretion of VEGF and VEGF receptor 2 and inactivated Akt kinase. Furthermore, A. sativum suppressed the secretion of proinflammatory cytokines such as Il-2, IL-6, Il-8, TNF- $\alpha$, IFN- $\gamma$ and enhanced the secretion of IL-10, an anti-inflammatory cytokine [153].

A. sativum also possesses antioxidative effects. Padiya et al. [154] pointed out that it reduced oxidative stress via AKT/PI3K/Nrf2-Keap1 pathway activation. In addition, garlic extracts inhibited peroxidation processes through the reduction of plasma methylenedioxyamphetamine (MDA) levels, and enhancement of various key antioxidant enzymes [155].

\subsubsection{Astragalus membranaceus}

A. membranaceus is a Chinese medicinal herb, which contains a wide range of bioactive chemical constituents: formononetin, adenosine, saccharose, calycosin, ononin, calycosin-7O-beta-D-glucoside, daucosterol, and 9,10-dimethoxypterocarpan-3-O-beta-D-glucoside. It has been reported as a useful anti-proliferative and antioxidant agent. Yoon-Sang et al. [156] administered A. membranaceus extracts to rats with surgically induced endometriosis. After 40 days, the volume of ectopic endometrial tissue areas was significantly lower. Furthermore, orally administered extracts of $A$. membranaceus decreased the concentration of estrogen, progesterone, IL-2 and TNF- $\alpha$. Other findings suggested that Astragalus roots suppressed estrogen-dependent endometrial cells proliferation and infertility-related ovarian dysfunctions [157]. According to Zhao et al. [158], the treatment with A. membranaceus and other Chinese medicinal herbs prevented the recurrence of endometriosis after conservative surgery, increased the fertility and had fewer side effects in comparison with the conventional medical treatment.

\subsubsection{Curcuma longa}

Curcuma longa is a medicinal herb also known as turmeric, whose major bioactive compound is represented by curcumin. Kong et al. [159] evaluated the effects of combined therapy with Tamoxifen and C. longa oil in rat endometriosis models. They reported that after the treatment, the volume of ectopic endometriotic foci significantly decreased, and the expression of VEGF was lower in comparison with controls.

C. longa extracts arrested endometriosis in dose-dependent manner. It inhibited the expression of MMP-9 and TNF- $\alpha$, and increased the levels of TIMP-1 [160]. Furthermore, C. longa increased the activity of IL-10-1082 A, an anti-inflammatory cytokine gene promoter [161]. Pro-apoptotic activity of $C$. longa has been demonstrated through the enhancement of caspase-3, 9, cytochrome $c$ and Bax [162].

A recent study [163] reported that daily administration of $200 \mathrm{mg} / \mathrm{kg}$ of the ethanolic extract of $C$. longa to endometriosis rat models decreased the oxidative stress. After the administration of the ethanolic extracts, the activity of SOD, CAT, and GPx significantly increased, while plasma MDA was lowered. Furthermore, according to Kuo et al. [164], C. longa regulated the expression of COX-2, iNOS, CAT, and NO, exerting both anti-oxidative and anti-inflammatory effects.

\subsubsection{Prunella vulgaris}

P. vulgaris belongs to Lamiaceae family. It has been used in European Medicine during the 17th century, due to its capacity to reduce fever. In China, it was also employed in folk medicine as antipyretic. This medicinal plant contains flavonoids, rosmaric acid, oleanolic acid, triterpenoids, prunelline, and tannins [165]. It displayed anti-estrogenic effects both 
in vitro and in vivo, and reduced the surface of endometriotic xenografts, being efficient in the management of estrogen-dependent disorders, such as endometriosis or uterine cancer [166].

P. vulgaris was also reported to possess anti-apoptotic effects. It increased the expression of caspase-3 and Bax, and decreased the expression of Bcl-2 [167]. As anti-inflammatory agent, $P$. vulgaris acted through the inhibition of p38 MAPK/ ERK signaling pathway and regulated TNF- $\alpha$-induced expression of adhesion molecules [168]. Considering all these findings, $P$. vulgaris could be a promising therapeutic alternative for the management of endometriosis.

\subsubsection{Sparganium stoloniferum}

Rhizoma sparganii represents the rhizome of S. stoloniferum, which is a Traditional Chinese Medicine, used for thousands of years for the treatment of bad stomach [169]. However, preliminary studies of $R$. sparganii suggested its pharmacological mechanisms also involved in angiogenesis and endocrine functions.

Sun et al. [170] investigated the effects of $R$. sparganii in pregnant rodents. They reported that $R$. sparganii significantly lowered the levels of FGF-1 and VEGF, and the expression of ER-alpha was inversely proportional to FGF-1. In these conditions, R. sparganii demonstrated its anti-angiogenic and anti-estrogenic activities. SpaTA is a novel polysaccharide isolated from the water extraction of $R$. sparganii. It induced apoptosis in breast cancer cells via caspase-3, 8, and 9 signaling and modulated estrogen signaling. Furthermore, SpaTA regulated the expression of ER-alpha and its nuclear translocation [171]. Topological analysis demonstrated that major targets of $S$. Stoloniferum include IL-8, EGFR, TNF, and VEGFA, which are several of the causal genes of endometriosis [22].

Taken together, all these results indicated that $S$. Stoloniferum could be an efficient therapeutic agent for the management of estrogen-dependent conditions, including endometriosis.

\subsubsection{Salvia miltiorrhiza (Danshen)}

S. miltiorrhiza is a perennial Chinese medicinal plant, included in the Lamiaceae family. Since ancient times, dried roots of S. miltiorrhiza, also known as Danshen, have been used for the management of cerebrovascular and cardiovascular pathologies [172]. The main bioactive compounds of Danshen are represented by tashinone I and II, cryptotanshinone and salvianolic acid. They possesses a wide range of beneficial pharmaceutical effects, such as anti-inflammatory, antioxidant, antitumoral, and antimicrobial properties [173].

In rat models, after the administration of tanshinone IIA, the growth of the ectopic endometrial tissue was significantly decreased, and the mechanical hyperalgesia was reduced. Moreover, the miRNA levels of angiotensinogen and angiotensin II were lowered in dorsal root ganglion neurons [174]. Tashinone IIA also increased the expression of Bax, a pro-apoptotic protein, and inhibited Bcl-xl and Bcl-2, two anti-apoptotic proteins [175]. Furthermore, this bioactive molecule demonstrated its antiangiogenic properties, by modulating VEGFA/HIF1- $\alpha$ signaling pathway and altering the MMP-2/TIMP-2 ratio in endothelial cells [176]. Tashinone I inhibited the formation of PGE2 from LPS-induced RAW macrophages, without affecting COX-2 expression and activity [177].

Zhou et al. [178] investigated the effects of S. miltiorrhiza on Sprague-Dawley rats. After the administration of S. miltiorrhiza extracts, serum CA-125 and the levels of IL-18 and TNF- $\alpha$ in the peritoneal fluid significantly were decreased, while peritoneal fluid levels of IL-13 increased, proving the anti-inflammatory properties of this medicinal herb. S. miltiorrhiza also showed strong antioxidant potential. Its constitutive polysaccharides increased the activity of GPx, SOD, CAT, MDA, and decreased MDA production [179]. In addition, a recent study pointed out that hydrophilic extract of $S$. miltiorrhiza remarkably enhanced SOD, GSH, and PONase levels [180]. 


\subsubsection{Paeonia lactiflora (Chishao)}

Paeonia lactiflora or Bái Sháo is a Chinese herbal medicine used for more than 1200 years, as a decoction of the dried roots. It is known for being useful in the treatment of dysmenorrhea, muscle cramps, fever, and rheumatoid arthritis. Paeonin is one of the most abundant bioactive compounds from P. lactiflora, and its pharmaceutical effects were investigated in vitro and in vivo. P. lactiflora extracts inhibited the production of PGE2, leukotriene B4 and NO in animal models. Furthermore, it induced the proliferation of lymphocytes, the differentiation of $\mathrm{T}$ helper and $\mathrm{T}$ suppressor lymphocytes, and inhibited the delayed-type hypersensitivity in immuno-activated animal models [181]. Paeoniflorin is another major compound of $P$. lactiflora. In postoperative mice, it significantly decreased the pain, via TLR4/MMP-9/MMP2/IL-1 $\beta$ signaling pathway [182].

Endometriosis is a progressive disease, and in some cases, it has a cancer-like behavior. $P$. lactiflora also possesses antitumor properties. Zhang et al. showed that P. lactiflora significantly decreased the proliferation of cancerous endometrial cells, in a dose-dependent manner, via the activation of NF- $\mathrm{kB}$ and MAPK signaling pathways [183]. Moreover, paeoniflorigenone, induced antiproliferative effects in tumor cell lines and enhanced apoptosis [184].

These results suggest that $P$. lactiflora may induce anti-inflammatory, immunomodulatory effects, and pro-apoptotic effects, and could be a beneficial alternative for the management of endometriosis.

\subsubsection{Viburnum opulus}

V. opulus, or European cranberry, belongs to Adoxaceae family and it is usually included in daily diet in juices, jelly, marmalade or jam [185]. It contains high amounts of anthocyanin and exerts potent antioxidative properties. In addition, these fruits possess anti-inflammatory, antimicrobial, antiviral, and antialgic properties [186].

In rat models with surgically-induced endometriosis, $V$. opulus significantly decreased the volume of endometriotic lesions, and lowered the serum levels of IL-6, VEGF and TNF- $\alpha$ [187]. It also possesses strong antioxidant capacity. According to Zayachkivska et al., V. opulus induced increased generation of NO, SOD, CAT, and suppressed MDA level and lipid peroxidation process [188].

\subsubsection{Cyperus rotundus}

C. rotundus or "Nagarmotha", is a medicinal plant used in China, India and Japan due to its beneficial effects against stomach disorders, spasms or bowel irritation. It has a high concentration of bioactive compounds, such as flavonoids, ascorbic acids, and phenolic acids. The rhizome of this herb exerts anti-inflammatory, analgesic, antioxidative, and antipyretic properties. In vitro, C. rotundus extracts prevented lipid peroxidation, thus demonstrating that this plant could be a potential source of antioxidants [189]. It is also widely used as anti-inflammatory agent. In endometriosis, C. rotundus decreased inflammation by mainly targeting the following pathways: HIF-1 signaling pathway, TNF and MAPK signaling pathway [22]. Moreover, it showed cytotoxic and pro-apoptotic effects on endometrial and ovarian tumoral cells [190].

\subsubsection{Euterpe oleracea}

E. oleracea is also known as Acai palm, and belongs to Arecaceae family. Usually, Acai berries are macerated with water, separated from their seeds and consumed as a purple-colored beverage [191]. Due to its antioxidant properties, Acai pulp is consumed as functional food.

Machado et al. [192] investigated the effects of E. oleracea on rat models with endometriosis. After the treatment, they observed a significant decrease of the endometriotic lesions surface. Furthermore, E. oleracea demonstrated its anti-inflammatory properties, by decreasing the levels of VEGF, PGE2, MMP-9, and COX-2. Through the activation of caspase-3, E. oleracea induced apoptosis and decreased cellular proliferation [193]. 
Velutin is a strong anti-inflammatory flavonoid isolated from the acai berries pulp. It was demonstrated that velutin reduces the production of TNF- $\alpha$ and IL-6, secondary to NF-kB inhibition. Velutin also blocked the degradation of NF- $\mathrm{kB}$ inhibitor and JNK phosphorylation [194].

E. oleracea possesses strong antioxidant properties. According to Zhou et al. [195] it lowers the oxidative stress by decreasing MDA and Nrf2 protein expression, and increasing the levels of SOD and GSH.

\subsubsection{Other Natural Products for Endometriosis Management}

Pycnogenol ${ }^{\circledR}$ is a natural antioxidant, a bark extract from Pinus pinaster. It contains a wide range of phenolic compounds such as taxifolin, catechin and procyanidins, and in the last years, it attracted the attention of many researchers in the field of endometriosis treatment, due to its strong free radical-scavenging activity against ROS [196]. Furthermore, Pycnogenol ${ }^{\circledR}$ is able to increase the efficiency of oral contraceptives for the treatment of endometriosis-related chronic pelvic pain [197]. According to Kohama et al. [198], Pycnogenol ${ }^{\circledR}$ reduced the pain scores without influencing the menstrual cycles pattern and the estrogen levels of endometriosis patients, and decreased serum levels of CA-125. This natural product, induced caspase-independent apoptosis and increased the antioxidant capacity in plasma [199].

Jing Tong Yu Shu is a traditional Chinese medicine with multiple beneficial effects. It consists of eleven herbs: Angelica sinensis, Asarum sieboldii, Cortex cinnamom, Cornus officinalis, Corydalis yanhusuo, Dioscorea polystachya, Foeniculi Fructus, Faeces trogopterori, Paeonia lactiflora Pallas, Radix cyathulae, and Whitmania pigra Whitman. Zhang et al. [200] reported that after four weeks of treatment with Jing Tong Yu Shu in endometriosis rat models, the volume of the ectopic endometrial tissue foci recorded a significant decrease. In addition, this traditional medicine significantly inhibited the secretion of IL-1 $\beta$ and IL-6 in the peritoneal fluid.

Urtica dioica roots and leaves have been used by ancient times for the treatment of menstrual hemorrhage, eczemas or rheumatism-related complaints. It has been demonstrated that hexane, ethyl acetate, and methanol extracts of $U$. dioica exhibited promising effects in endometriosis rat models. After the administration of this extracts obtained by the aerial parts of $U$. dioica, the levels of IL-6, TNF- $\alpha$, and VEGF were significantly lowered [201].

Zingiber officinale, also known as Ginger, is a widely used root in Asian cuisine; also, it is used as medicine, due to its multiple beneficial pharmaceutical properties. Shagaols, are bioactive compounds found in dried ginger, which possess anti-inflammatory, anticancer, antioxidant, and neuroprotective activities [202]. Wang et al. [203] explored the effects of 6-shogaol on endometriosis rats models and described the main anti-inflammatory pathways of this bioactive compound. After one month of oral gavage with 6-shagol, the surface of the endometriotic lesions was reduced, the histological analysis suggesting atrophy and major regression. 6-shagol modulated the expression of VEGF and VEGFR-2 and down-regulated NF- $\mathrm{KB}$ signaling. Furthermore, pro-inflammatory factors such as IL-6, IL-1 $\beta$, PGE2 and NO were suppressed. In these conditions, Z. officinale extracts seem to be promising therapeutic agents for the management of endometriosis.

Table 1 summarizes the main biological effects of herbal medicine against endometriosis and their mechanisms of action. 


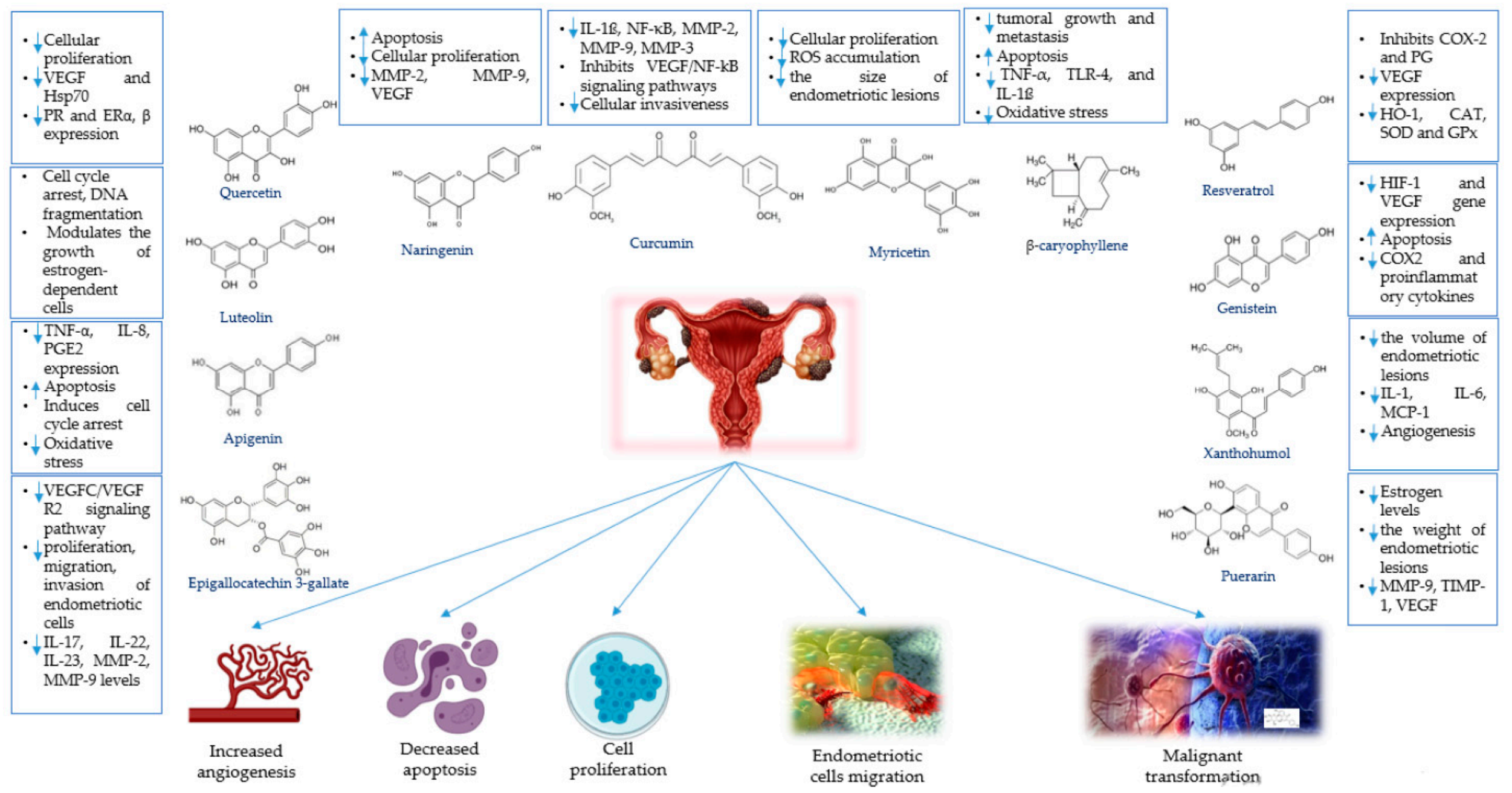

Figure 1. Endometriosis pathogenic mechanisms and the main mechanisms of action of various phytochemicals. 
Table 1. Medicinal herbs and their effects against endometriosis.

\begin{tabular}{|c|c|c|c|c|}
\hline Medicinal Plant & Experimental Model & Biological Effects & Molecular Mechanisms & Reference \\
\hline Angelica sinensis & $\begin{array}{l}\text { Rats with surgically induced } \\
\text { endometriosis (human } \\
\text { endometriotic cells) }\end{array}$ & $\begin{array}{l}\text { - } \quad \text { Reduced the number of } \\
\text { endometriotic lesions } \\
\text { - } \quad \text { Anti-inflammatory effects }\end{array}$ & $\begin{array}{l}\text { Decreased the levels of IL-18, TNF- } \alpha \text {, } \\
\text { MMP-2, MMP-9, and CA-125 } \\
\text { - Increased the levels of IL-13 }\end{array}$ & [140] \\
\hline Achillea biebersteinii & $\begin{array}{l}\text { Rats with surgically induced } \\
\text { endometriosis } \\
\text { Mouse pain models }\end{array}$ & 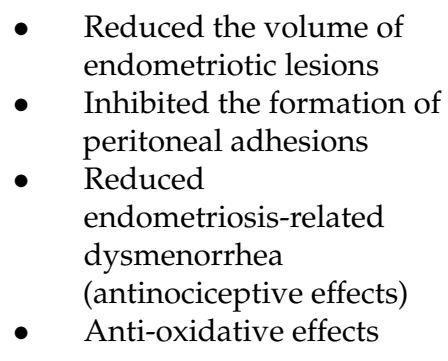 & $\begin{array}{l}\text { Decreased the levels of IL-6, TNF- } \alpha \text {, } \\
\text { VEGF } \\
\text { Inhibited the nociceptive receptors and } \\
\text { its effects were blocked by Atropine }\end{array}$ & [143-145] \\
\hline Artemisia princeps & Human endometriotic cells & $\begin{array}{ll}\text { - } & \text { Increased apoptosis in } \\
\text { - } & \text { Andometriotic cells } \\
\text { - } & \text { Anti-inflammatifory effects } \\
\text { - } & \text { Anti-oxidative effects }\end{array}$ & $\begin{array}{l}\text { Inhibited the expression of Bcl-2, } \\
\text { Bcl-xL, XIAP, caspase 3, caspase } 8 \text { and } \\
\text { caspase } 9 \\
\text { Induced cell cycle arrest in G2/M } \\
\text { phase } \\
\text { Decreased the levels of of TNF- } \alpha \text {, } \\
\text { ICAM-1, IL-1ß, and VCAM-1 } \\
\text { - Suppressed RO, NO and iNOS } \\
\text { expression in LPS-induced } \\
\text { macrophages }\end{array}$ & [148-151] \\
\hline
\end{tabular}


Table 1. Cont

\begin{tabular}{|c|c|c|c|c|}
\hline Medicinal Plant & Experimental Model & Biological Effects & Molecular Mechanisms & Reference \\
\hline Allium sativum & Human endometriotic cells & $\begin{array}{ll}\text { - } & \text { Reduced cellular proliferation } \\
\text { - } & \text { Induced apoptosis } \\
\text { - } & \text { Anti-angiogenic activity }\end{array}$ & $\begin{array}{l}\text { - Reduced the expression of VCAM-1 } \\
\text { and ICAM-1 } \\
\text { - Increased the activity of caspase-3 and } \\
\text { Bax expression } \\
\text { - Decreased VEGF and VEGFR } \\
\text { expression }\end{array}$ & {$[151,153]$} \\
\hline Astragalus membranaceus & $\begin{array}{c}\text { Rats with surgically induced } \\
\text { endometriosis }\end{array}$ & $\begin{array}{l}\text { Decreased the volume of } \\
\text { endometriotic lesions } \\
\text { - Anti-estrogenic and } \\
\text { anti-progestative effects } \\
\text { - Anti-inflammatory effects }\end{array}$ & $\begin{array}{l}\text { Decreased the concentrations of IL-2, } \\
\text { TNF- } \alpha \text {, estrogen and progesterone }\end{array}$ & [156] \\
\hline Curcuma longa & $\begin{array}{l}\text { Rat with surgically induced } \\
\text { endometriosis }\end{array}$ & $\begin{array}{l}\text { - } \quad \text { Decreased the volume of } \\
\text { endometriotic lesions } \\
\text { - } \quad \text { Anti-angiogenic effects } \\
\text { - } \quad \text { Anti-inflammatory effects } \\
\text { - } \quad \text { Pro-apoptotic effects } \\
\text { - }\end{array}$ & $\begin{array}{l}\text { - Suppressed the expression of VEGF, } \\
\text { MMP-9, TIMP-1 and TNF- } \alpha \\
\text { - Increased the activity of IL-10-1082 A } \\
\text { Increased the activity of caspase-3, } \\
\text { caspase-9 and Bax } \\
\text { Increased serum levels of SOD, CAT } \\
\text { and GPx }\end{array}$ & [159-163] \\
\hline
\end{tabular}


Table 1. Cont.

\begin{tabular}{|c|c|c|c|c|}
\hline Medicinal Plant & Experimental Model & Biological Effects & Molecular Mechanisms & Reference \\
\hline Prunella vulgaris & Xenograft mice & - $\quad$ Anti-estrogenic effects & $\begin{array}{l}\text { - Inhibited the expression of CYR61, } \\
\text { CYP1A1, CYP1B1 } \\
\text { - } \quad \text { Induced decreased proliferation of ER }\end{array}$ & [166] \\
\hline Rhizoma sparganii & Pregnant rodents & $\begin{array}{l}\text { - } \quad \text { Anti-estrogenic effects } \\
\text { - } \quad \text { Anti-angiogenic effects }\end{array}$ & $\begin{array}{l}\text { - Decreased the levels of FGF-1, VEGF, } \\
\text { and ER- } \alpha\end{array}$ & [170] \\
\hline Salvia miltiorrhiza & $\begin{array}{c}\text { Rats with surgically induced } \\
\text { endometriosis }\end{array}$ & $\begin{array}{l}\text { - } \quad \text { Inhibited the growth of } \\
\text { endometriotic lesions } \\
\text { - } \quad \text { Reduced hyperalgesia } \\
\text { - } \quad \text { Anti-inflammatory effects }\end{array}$ & $\begin{array}{l}\text { Decreased miRNA levels of } \\
\text { angiotensinogen and angiotensin II in } \\
\text { dorsal root ganglion neurons } \\
\text { Decreased the levels of IL-18, TNF- } \alpha \text { in } \\
\text { the peritoneal fluid }\end{array}$ & {$[174,178]$} \\
\hline
\end{tabular}


Table 1. Cont.

\begin{tabular}{|c|c|c|c|c|}
\hline Medicinal Plant & Experimental Model & Biological Effects & Molecular Mechanisms & Reference \\
\hline Paeonia lactiflora & Tumoral endometrial cells & - $\quad$ Anti-proliferative effects & $\begin{array}{l}\text { - Activated NF- } \mathrm{kB} \text { and MAPK signaling } \\
\text { pathways }\end{array}$ & [183] \\
\hline Viburnum opulus & $\begin{array}{l}\text { Rats with surgically induced } \\
\text { endometriosis }\end{array}$ & $\begin{array}{l}\text { - Decreased the volume of the } \\
\text { lesions } \\
\text { - Exhibited antioxidant } \\
\text { capacity }\end{array}$ & $\begin{array}{l}\text { - } \quad \text { Decreased IL-6, VEGF and TNF- } \alpha \\
\text { Increased the levels and activity of NO, } \\
\text { SOD, CAT }\end{array}$ & {$[187,188]$} \\
\hline Cyperus rotundus & Human endometrial cells & - Anti-inflammatory effects & $\begin{array}{l}\text { - Targeted HIF-1 signaling pathway, } \\
\text { TNF and MAPK signaling pathway }\end{array}$ & [22] \\
\hline Euterpe oleracea & $\begin{array}{l}\text { Rats with surgically induced } \\
\text { endometriosis }\end{array}$ & $\begin{array}{l}\text { - Decreased the surface of the } \\
\text { lesions } \\
\text { - Anti-inflammatory and } \\
\text { pro-apoptotic effects }\end{array}$ & $\begin{array}{l}\text { - } \quad \text { Decreased the level of VEGF, PGE2, } \\
\text { MMp-9, COX-2 } \\
\text { - } \quad \text { Activated caspase-3 }\end{array}$ & [193] \\
\hline
\end{tabular}


Table 1. Cont

\begin{tabular}{|c|c|c|c|c|}
\hline Medicinal Plant & Experimental Model & Biological Effects & Molecular Mechanisms & Reference \\
\hline Pinus pinaster & Human clinical trial & $\begin{array}{l}\text { - } \quad \text { Reduced the chronic pain } \\
\text { scores } \\
\text { - } \quad \text { Pro-apoptotic effects }\end{array}$ & $\begin{array}{l}\text { - Decreased the levels of CA-125, } \\
\text { modulated caspases activity }\end{array}$ & {$[198,199]$} \\
\hline Urtica dioica & $\begin{array}{c}\text { Rats with surgically induced } \\
\text { endometriosis }\end{array}$ & $\begin{array}{l}\text { - Anti-inflammatory effects } \\
\text { - Anti-angiogenic effects }\end{array}$ & $\begin{array}{l}\text { - Decreased the level of, the levels of } \\
\text { IL-6, TNF- } \alpha \\
\text { - Suppressed VEGF }\end{array}$ & [201] \\
\hline Zinguber officinale & $\begin{array}{l}\text { Rats with surgically induced } \\
\text { endometriosis }\end{array}$ & 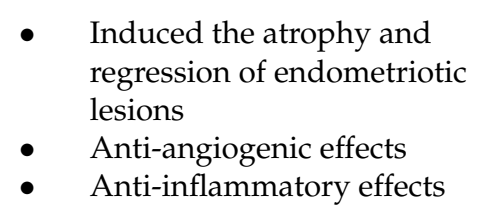 & $\begin{array}{l}\text { - } \quad \text { Decreased the expression of VEGF and } \\
\text { VEGFR } \\
\text { - } \quad \text { Down-regulated NF- } \mathrm{kB} \text { signaling } \\
\text { Decreased the levels of IL-6, IL-1 } \beta \text {, } \\
\text { PGE2, NO }\end{array}$ & [203] \\
\hline
\end{tabular}




\section{Conclusions}

Despite being a benign gynecological condition, endometriosis continues to be a debilitating disease for young women in reproductive age, due to the symptoms that it develops. Chronic pelvic pain, vaginal bleeding, infertility, and malignant transformation are the most widely encountered symptoms. Considering the lack of specific symptoms and specific biomarkers for endometriosis diagnosis, the accurate diagnosis could be delayed for years, and the gold-standard remains surgery followed by histopathological exam. Medicinal herbs and their bioactive compounds exhibit anti-angiogenic, antioxidant, sedative and pain-alleviating properties and the beneficial effects recorded until now encourage their use for the management of endometriosis.

In this paper, we described the pharmaceutical activity of 13 phytochemicals and 17 medicinal plants, including those used by centuries for the Traditional Chinese Medicine. All these natural compounds are able to interact with multiple biological processes, resulting in the alleviation of endometriosis-related complaints. However, future human randomized clinical trials would be helpful in order to achieve more conclusive results about the efficiency of herbal medicine as alternative therapy in endometriosis.

In our opinion, the administration of herbal therapy to the patients with endometriosis could be a topic of great interest for the supporters of natural therapies. Low cost, decreased number of side effects, increased bioavailability, as well as the favorable results reported until now are several of the arguments that could support the naturopathic treatment of this pathology. However, considering that the etiopathology of endometriosis is so debated and not fully elucidated, it requires caution in deciding the therapeutic management. Moreover, the lack of human clinical trials represents a major disadvantage for this therapy, although in vitro and in vivo studies are very promising.

Therefore, we consider medicinal plants and phytochemicals excellent adjuncts in the treatment of endometriosis, but they are currently insufficient as unique therapeutic tools. The decision to consume such dietary supplements must be made with a doctor.

Author Contributions: Conceptualization, M.A.M. and L.D.; methodology, A.B; validation, C.V.A.; investigation, C.G.D.; data curation, C.C.M. and C.V.A.; writing-original draft preparation, A.B. and D.E.P.; supervision, C.A.I. All authors have read and agreed to the published version of the manuscript.

Funding: This research received no external funding.

Institutional Review Board Statement: Not applicable.

Conflicts of Interest: The authors declare no conflict of interest.

$\begin{array}{ll}\text { Abbreviations } \\ \text { CAT } & \text { Catalase } \\ \text { COX-2 } & \text { Cyclooxygenase-2 } \\ \text { DNA } & \text { Deoxyribonucleic acid } \\ \text { E2 } & \text { Estradiol } \\ \text { ECM } & \text { Extracellular matrix } \\ \text { EGCG } & \text { Epigallocatechin-3-gallate } \\ \text { EGFR } & \text { Epithelial growth factor receptor } \\ \text { ER } & \text { Estrogen receptor } \\ \text { GnRH } & \text { Gonadotropin-releasing hormone } \\ \text { GSH } & \text { Glutathione } \\ \text { GSH-Px } & \text { Glutathione peroxidase } \\ \text { HIF } & \text { Hypoxia-inducible factor } \\ \text { HSP70 } & \text { Heat shock protein 70 } \\ \text { ICAM-1 } & \text { Intercellular Adhesion Molecule 1 } \\ \text { IFN } & \text { Interferon } \\ \text { IL } & \text { Interleukin }\end{array}$




$\begin{array}{ll}\text { iNOS } & \text { Nitric oxide synthase } \\ \text { LPS } & \text { Lipopolysaccharide } \\ \text { MAPK } & \text { Mitogen-activated protein kinase } \\ \text { MDA } & \text { Methylenedioxyamphetamine } \\ \text { MeSH } & \text { Medical Subject Headings } \\ \text { MIF } & \text { Macrophage migration inhibitory factor } \\ \text { miRNA } & \text { Micro-ribonucleic acid } \\ \text { MMP } & \text { Matrix metalloproteinase } \\ \text { NF-kB } & \text { Nuclear factor } \text { } B \\ \text { NO } & \text { Nitric oxide } \\ \text { NSAID } & \text { Nonsteroidal anti-inflammatory drugs } \\ \text { P38 } & \text { Protein 38 } \\ \text { PG } & \text { Prostaglandin } \\ \text { PGE2 } & \text { Prostaglandin E2 } \\ \text { PK-1 } & \text { Prokinetitsina-1 } \\ \text { PONase } & \text { Paraoxonase } \\ \text { PR } & \text { Progesterone receptor } \\ \text { ROS } & \text { Reactive oxygen species } \\ \text { RTK } & \text { Receptor tyrosine kinase } \\ \text { SOD } & \text { Superoxide dismutase } \\ \text { TCM } & \text { Traditional Chinese Medicine } \\ \text { TGF- } \beta & \text { Transforming growth factor beta } \\ \text { TIMP } & \text { Tissue inhibitors of metalloproteinase } \\ \text { TLR } & \text { Toll-like receptor } \\ \text { TNF- } \alpha & \text { Tumor necrosis factor-alpha } \\ \text { TSP-1 } & \text { Thrombospondin-1 } \\ \text { VEGF } & \text { Vascular endothelial growth factor } \\ \text { VEGFC } & \text { Vascular endothelial growth factor C } \\ \text { VEGFR } & \text { Vascular endothelial growth factor receptor } \\ & \end{array}$

\section{References}

1. Parasar, P.; Ozcan, P.; Terry, K.L. Endometriosis: Epidemiology, Diagnosis and Clinical Management. Curr. Obstet. Gynecol. Rep. 2017, 6, 34-41. [CrossRef] [PubMed]

2. Ahn, S.H.; Monsanto, S.P.; Miller, C.; Singh, S.S.; Thomas, R.; Tayade, C. Pathophysiology and Immune Dysfunction in Endometriosis. Biomed. Res. Int. 2015, 2015, 795976. [CrossRef] [PubMed]

3. Anastasiu, C.-V.; Moga, M.; Neculau, A.; Bălan, A.; Scarneciu, I.; Dragomir, R.; Dull, A.-M.; Chicea, L. Biomarkers for the Noninvasive Diagnosis of Endometriosis: State of the Art and Future Perspectives. Int. J. Mol. Sci. 2020, 21, 1750. [CrossRef]

4. Bina, F.; Soleymani, S.; Toliat, T.; Hajimahmoodi, M.; Tabarrai, M.; Abdollahi, M.; Rahimi, R. Plant-derived medicines for treatment of endometriosis: A comprehensive review of molecular mechanisms. Pharmacol. Res. 2019, 139, 76-90. [CrossRef] [PubMed]

5. Moga, M.A.; Bălan, A.; Dimienescu, O.G.; Burtea, V.; Dragomir, R.M.; Anastasiu, C.V. Circulating miRNAs as Biomarkers for Endometriosis and Endometriosis-Related Ovarian Cancer-An Overview. J. Clin. Med. 2019, 8, 735. [CrossRef]

6. Andres, M.P.; Arcoverde, F.V.L.; Souza, C.C.C.; Fernandes, L.F.C.; Abrão, M.S.; Kho, R.M. Extrapelvic Endometriosis: A Systematic Review. J. Minim. Invasive Gynecol. 2020, 27, 373-389. [CrossRef]

7. Yovich, J.L.; Rowlands, P.K.; Lingham, S.; Sillender, M.; Srinivasan, S. Pathogenesis of endometriosis: Look no further than John Sampson. Reprod. BioMed. Online 2020, 40, 7-11. [CrossRef]

8. Sasson, I.E.; Taylor, H.S. Stem cells and the pathogenesis of endometriosis. Ann. N. Y. Acad. Sci. 2008, 1127, 106-115. [CrossRef]

9. Harirchian, P.; Gashaw, I.; Lipskind, S.T.; Braundmeier, A.G.; Hastings, J.M.; Olson, M.R.; Fazleabas, A.T. Lesion kinetics in a non-human primate model of endometriosis. Hum. Hum. Reprod. 2012, 27, 2341-2351. [CrossRef]

10. Hapangama, D. Theories on the Pathogenesis of Endometriosis. Int. J. Reprod. Med. 2014, 2014, 1-9. [CrossRef]

11. Dehoux, J.-P.; Defrere, S.; Squifflet, J.; Donnez, O.; Polet, R.; Mestdagt, M.; Foidart, J.-M.; Van Langendonckt, A.; Donnez, J. Is the baboon model appropriate for endometriosis studies? Fertil. Steril. 2011, 96, 728-733.e723. [CrossRef]

12. Koninckx, P.R.; Ussia, A.; Adamyan, L.; Wattiez, A.; Gomel, V.; Martin, D.C. Pathogenesis of endometriosis: The genetic/epigenetic theory. Fertil. Steril. 2019, 111, 327-340. [CrossRef]

13. Laganà, A.S.; Salmeri, F.M.; Vitale, S.G.; Triolo, O.; Götte, M. Stem Cell Trafficking During Endometriosis: May Epigenetics Play a Pivotal Role? Reprod. Sci. 2018, 25, 978-979. [CrossRef]

14. Ghai, V.; Jan, H.; Shakir, F.; Haines, P.; Kent, A. Diagnostic delay for superficial and deep endometriosis in the United Kingdom. J. Obstet. Gynaecol. 2020, 40, 83-89. [CrossRef]

15. Becker, C.; Gattrell, W.; Gude, K.; Singh, S. Reevaluating response and failure of medical treatment of endometriosis: A systematic review. J. Fertil. Steril. 2017, 108, 125-136. [CrossRef] 
16. Bedaiwy, M.A.; Alfaraj, S.; Yong, P.; Casper, R. New developments in the medical treatment of endometriosis. Fertil. Steril. 2017, 107, 555-565. [CrossRef]

17. Dunselman, G.A.J.; Vermeulen, N.; Becker, C.; Calhaz-Jorge, C.; D’Hooghe, T.; De Bie, B.; Heikinheimo, O.; Horne, A.W.; Kiesel, L.; Nap, A.; et al. ESHRE guideline: Management of women with endometriosis. Hum. Reprod. 2014, 29, 400-412. [CrossRef] [PubMed]

18. Zhao, Y.; Gong, P.; Chen, Y.; Nwachukwu, J.C.; Srinivasan, S.; Ko, C.; Bagchi, M.K.; Taylor, R.N.; Korach, K.S.; Nettles, K.W.; et al. Dual suppression of estrogenic and inflammatory activities for targeting of endometriosis. Sci. Transl. Med. 2015, 7, 271ra279. [CrossRef] [PubMed]

19. Luu, T.H.; Uy-Kroh, M.J. New Developments in Surgery for Endometriosis and Pelvic Pain. Clin. Obstet. Gynecol. 2017, 60, 245-251. [CrossRef]

20. Flower, A.; Liu, J.P.; Chen, S.; Lewith, G.; Little, P. Chinese herbal medicine for endometriosis. Cochrane Database Syst Rev. 2009, Cd006568. [CrossRef]

21. Ashrafizaveh, A.; Sabouri Fard, H.; Azmoudeh, E. Application of Medicinal Plants, Acupuncture, Massage Therapy and Transcutaneous Electric Nerve Stimulation in Treatment of Endometriosis: Review Study. Iran. J. Obstet. Gynecol. Infertil. 2019, 22, 90-100.

22. Zheng, W.; Wu, J.; Gu, J.; Weng, H.; Wang, J.; Wang, T.; Liang, X.; Cao, L. Modular Characteristics and Mechanism of Action of Herbs for Endometriosis Treatment in Chinese Medicine: A Data Mining and Network Pharmacology-Based Identification. Front. Pharmacol. 2020, 11, 147. [CrossRef]

23. Su, S.Y.; Muo, C.H.; Sung, F.C.; Morisky, D.E. Reduction of surgery rate in endometriosis patients who take Chinese medicine: A population-based retrospective cohort study. Complement. Ther. Med. 2014, 22, 632-639. [CrossRef] [PubMed]

24. Zheng, W.; Cao, L.; Xu, Z.; Ma, Y.; Liang, X. Anti-Angiogenic Alternative and Complementary Medicines for the Treatment of Endometriosis: A Review of Potential Molecular Mechanisms. Evid. Complement. Altern. Med. 2018, 2018, 4128984. [CrossRef] [PubMed]

25. Lousse, J.C.; Van Langendonckt, A.; Defrere, S.; Ramos, R.G.; Colette, S.; Donnez, J. Peritoneal endometriosis is an inflammatory disease. Front. Biosci. 2012, 4, 23-40. [CrossRef]

26. Oral, E.; Olive, D.L.; Arici, A. The peritoneal environment in endometriosis. Hum. Reprod. Update 1996, 2, 385-398. [CrossRef] [PubMed]

27. Gazvani, R.; Templeton, A. Peritoneal environment, cytokines and angiogenesis in the pathophysiology of endometriosis. Reproduction 2002, 123, 217-226. [CrossRef]

28. Wu, M.-H.; Shoji, Y.; Chuang, P.-C.; Tsai, S.-J. Endometriosis: Disease pathophysiology and the role of prostaglandins. Expert Rev. Mol. Med. 2007, 9, 1-20. [CrossRef] [PubMed]

29. Wu, M.-H.; Lu, C.-W.; Chuang, P.-C.; Tsai, S.-J. Prostaglandin E2: The master of endometriosis? Exp. Biol. Med. 2010, $235,668-677$. [CrossRef] [PubMed]

30. Narumiya, S.; Sugimoto, Y.; Ushikubi, F. Prostanoid receptors: Structures, properties, and functions. Physiol. Rev. 1999, 79, 1193-1226. [CrossRef]

31. Sugino, N.; Karube-Harada, A.; Taketani, T.; Sakata, A.; Nakamura, Y. Withdrawal of ovarian steroids stimulates prostaglandin F2alpha production through nuclear factor-kappaB activation via oxygen radicals in human endometrial stromal cells: Potential relevance to menstruation. J. Reprod. Dev. 2004, 50, 215-225. [CrossRef]

32. Banu, S.K.; Lee, J.; Speights, V.O., Jr.; Starzinski-Powitz, A.; Arosh, J.A. Cyclooxygenase-2 Regulates Survival, Migration, and Invasion of Human Endometriotic Cells through Multiple Mechanisms. Endocrinology 2008, 149, 1180-1189. [CrossRef]

33. González-Ramos, R.; Van Langendonckt, A.; Defrère, S.; Lousse, J.C.; Colette, S.; Devoto, L.; Donnez, J. Involvement of the nuclear factor- $\mathrm{kB}$ pathway in the pathogenesis of endometriosis. Fertil. Steril. 2010, 94, 1985-1994. [CrossRef]

34. González-Ramos, R.; Van Langendonckt, A.; Defrère, S.; Lousse, J.C.; Mettlen, M.; Guillet, A.; Donnez, J. Agents Blocking the Nuclear Factor- $\mathrm{B}$ Pathway Are Effective Inhibitors of Endometriosis in an in vivo Experimental Model. Gynecol. Obstet. Investig. 2008, 65, 174-186. [CrossRef]

35. Dull, A.-M.; Moga, M.A.; Dimienescu, O.G.; Sechel, G.; Burtea, V.; Anastasiu, C.V. Therapeutic Approaches of Resveratrol on Endometriosis via Anti-Inflammatory and Anti-Angiogenic Pathways. Molecules 2019, 24, 667. [CrossRef] [PubMed]

36. Wu, M.-H.; Hsiao, K.-Y.; Tsai, S.-J. Endometriosis and possible inflammation markers. Gynecol. Minim. Invasive Ther. 2015, 4, 61-67. [CrossRef]

37. Brinckerhoff, C.E.; Matrisian, L.M. Matrix metalloproteinases: A tail of a frog that became a prince. Nat. Rev. Mol. Cell Biol. 2002, 3, 207-214. [CrossRef]

38. Page-McCaw, A.; Ewald, A.J.; Werb, Z. Matrix metalloproteinases and the regulation of tissue remodelling. Nat. Rev. Mol. Cell Biol. 2007, 8, 221-233. [CrossRef]

39. Brew, K.; Nagase, H. The tissue inhibitors of metalloproteinases (TIMPs): An ancient family with structural and functional diversity. Mol. Cell Res. 2010, 1803, 55-71. [CrossRef]

40. Osteen, K.G.; Yeaman, G.R.; Bruner-Tran, K.L. Matrix metalloproteinases and endometriosis. Semin. Reprod. Med. 2003, 21, 155-164. [CrossRef]

41. Paul, S.; Bhattacharya, P.; Mahapatra, P.; Swarnakar, S. Melatonin protects against endometriosis via regulation of matrix metalloproteinase-3 and an apoptotic pathway. J. Pineal Res. 2010, 49, 156-168. [CrossRef] [PubMed] 
42. Jana, S.; Paul, S.; Swarnakar, S. Curcumin as anti-endometriotic agent: Implication of MMP-3 and intrinsic apoptotic pathway. Biochem. Pharmacol. 2012, 83, 797-804. [CrossRef]

43. Iurlaro, M.; Loverro, G.; Vacca, A.; Cormio, G.; Ribatti, D.; Minischetti, M.; Ria, R.; Bruno, M.; Selvaggi, L. Angiogenesis extent and expression of matrix metalloproteinase-2 and-9 correlate with upgrading and myometrial invasion in endometrial carcinoma. Eur. J. Clin. Investig. 1999, 29, 793-801. [CrossRef] [PubMed]

44. Li, Z.G.; Lang, J.H.; Leng, J.H.; Liu, D.Y. Increased levels of prostaglandin E2 and bcl-2 in peritoneal fluid and serum of patients with endometriosis. Zhonghua Fu Chan Ke Za Zhi 2005, 40, 598-600.

45. Huang, H.F.; Hong, L.H.; Tan, Y.; Sheng, J.Z. Matrix metalloproteinase 2 is associated with changes in steroid hormones in the sera and peritoneal fluid of patients with endometriosis. Fertil. Steril. 2004, 81, 1235-1239. [CrossRef] [PubMed]

46. Gupta, S.; Agarwal, A.; Krajcir, N.; Alvarez, J.G. Role of oxidative stress in endometriosis. Reprod. BioMed. Online. 2006, 13, 126-134. [CrossRef]

47. Ruder, E.H.; Hartman, T.J.; Blumberg, J.; Goldman, M.B. Oxidative stress and antioxidants: Exposure and impact on female fertility. Hum. Reprod. Update 2008, 14, 345-357. [CrossRef] [PubMed]

48. Aon, M.A.; Cortassa, S.; O'Rourke, B. Redox-optimized ROS balance: A unifying hypothesis. Biochim. Biophys. Acta. 2010, 1797, 865-877. [CrossRef] [PubMed]

49. Agarwal, A.; Aponte-Mellado, A.; Premkumar, B.J.; Shaman, A.; Gupta, S. The effects of oxidative stress on female reproduction: A review. Reprod. Biol. Endocrinol. 2012, 10, 49. [CrossRef]

50. Van Langendonckt, A.; Casanas-Roux, F.; Donnez, J. Oxidative stress and peritoneal endometriosis. Fertil. Steril. 2002, 77, 861-870. [CrossRef]

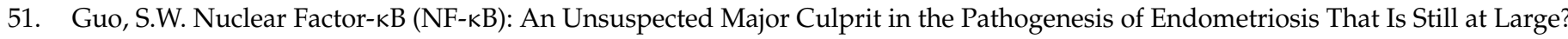
Gynecol. Obstet. Investig. 2007, 63, 71-97. [CrossRef]

52. González-Ramos, R.; Donnez, J.; Defrère, S.; Leclercq, I.; Squifflet, J.; Lousse, J.-C.; Van Langendonckt, A. Nuclear factor-kappa B is constitutively activated in peritoneal endometriosis. Mol. Hum. Reprod. 2007, 13, 503-509. [CrossRef] [PubMed]

53. Lousse, J.C.; Van Langendonckt, A.; González-Ramos, R.; Defrère, S.; Renkin, E.; Donnez, J. Increased activation of nuclear factor-kappa B (NF-kappaB) in isolated peritoneal macrophages of patients with endometriosis. Fertil. Steril. 2008, 90, 217-220. [CrossRef]

54. Dalton, T.P.; Shertzer, H.G.; Puga, A. Regulation of gene expression by reactive oxygen. Annu. Rev. Pharmacol. Toxicol. 1999, 39, 67-101. [CrossRef] [PubMed]

55. Hey-Cunningham, A.J.; Peters, K.M.; Zevallos, H.B.; Berbic, M.; Markham, R.; Fraser, I.S. Angiogenesis, lymphangiogenesis and neurogenesis in endometriosis. Front. Biosci. 2013, 5, 1033-1056. [CrossRef]

56. Gargett, C.E.; Masuda, H. Adult stem cells in the endometrium. Mol. Hum. Reprod. 2010, 16, 818-834. [CrossRef] [PubMed]

57. Esser, S.; Lampugnani, M.G.; Corada, M.; Dejana, E.; Risau, W. Vascular endothelial growth factor induces VE-cadherin tyrosine phosphorylation in endothelial cells. J. Cell Sci. 1998, 111 Pt 13, 1853-1865.

58. Kevil, C.G.; Payne, D.K.; Mire, E.; Alexander, J.S. Vascular permeability factor/vascular endothelial cell growth factor-mediated permeability occurs through disorganization of endothelial junctional proteins. J. Biol. Chem. 1998, 273, 15099-15103. [CrossRef] [PubMed]

59. Ferrara, N. Role of vascular endothelial growth factor in regulation of physiological angiogenesis. Am. J. Physiol. Cell Physiol. 2001, 280, C1358-C1366. [CrossRef] [PubMed]

60. Senger, D.R.; Claffey, K.P.; Benes, J.E.; Perruzzi, C.A.; Sergiou, A.P.; Detmar, M. Angiogenesis promoted by vascular endothelial growth factor: Regulation through alpha1beta1 and alpha2beta1 integrins. Proc. Natl. Acad. Sci. USA 1997, 94, 13612-13617. [CrossRef]

61. Pardo, O.E.; Arcaro, A.; Salerno, G.; Raguz, S.; Downward, J.; Seckl, M.J. Fibroblast growth factor-2 induces translational regulation of Bcl-XL and Bcl-2 via a MEK-dependent pathway. Correlation with resistance to etoposide-induced apoptosis. J. Biol. Chem. 2015, 290, 15390. [CrossRef] [PubMed]

62. Lee, K.F.; Lee, Y.L.; Chan, R.W.; Cheong, A.W.; Ng, E.H.; Ho, P.C.; Yeung, W.S. Up-regulation of endocrine gland-derived vascular endothelial growth factor but not vascular endothelial growth factor in human ectopic endometriotic tissue. Fertil. Steril. 2010, 93, 1052-1060. [CrossRef]

63. Kerr, J.F.; Wyllie, A.H.; Currie, A.R. Apoptosis: A basic biological phenomenon with wide-ranging implications in tissue kinetics. Br. J. Cancer. 1972, 26, 239-257. [CrossRef]

64. Reed, J.C. Mechanisms of apoptosis. Am. J. Pathol. 2000, 157, 1415-1430. [CrossRef]

65. Galluzzi, L.; Vitale, I.; Abrams, J.M.; Alnemri, E.S.; Baehrecke, E.H.; Blagosklonny, M.V.; Dawson, T.M.; Dawson, V.L.; El-Deiry, W.S.; Fulda, S.; et al. Molecular definitions of cell death subroutines: Recommendations of the Nomenclature Committee on Cell Death 2012. Cell Death Differ. 2012, 19, 107-120. [CrossRef]

66. Shi, Y. Mechanical aspects of apoptosome assembly. Curr. Opin. Cell Biol. 2006, 18, 677-684. [CrossRef]

67. Harada, T.; Taniguchi, F.; Izawa, M.; Ohama, Y.; Takenaka, Y.; Tagashira, Y.; Ikeda, A.; Watanabe, A.; Iwabe, T.; Terakawa, N. Apoptosis and endometriosis. Front. Biosci. 2007, 12, 3140-3151. [CrossRef] [PubMed]

68. Pan, Q.; Luo, X.; Toloubeydokhti, T.; Chegini, N. The expression profile of micro-RNA in endometrium and endometriosis and the influence of ovarian steroids on their expression. Mol. Hum. Reprod. 2007, 13, 797-806. [CrossRef] [PubMed] 
69. Shi, X.-Y.; Gu, L.; Chen, J.; Guo, X.-R.; Shi, Y.-L. Downregulation of miR-183 inhibits apoptosis and enhances the invasive potential of endometrial stromal cells in endometriosis. Int. J. Mol. Med. 2014, 33, 59-67. [CrossRef] [PubMed]

70. Tian, X.; Xu, L.; Wang, P. MiR-191 inhibits TNF- $\alpha$ induced apoptosis of ovarian endometriosis and endometrioid carcinoma cells by targeting DAPK1. Int. J. Clin. Exp. Pathol. 2015, 8, 4933-4942.

71. Corte, L.D.; Noventa, M.; Ciebiera, M.; Magliarditi, M.; Sleiman, Z.; Karaman, E.; Catena, U.; Salvaggio, C.; Falzone, G.; Garzon, S. Phytotherapy in endometriosis: An up-to-date review \%J Journal of Complementary and Integrative Medicine. J. Complement. Integr. Med. 2019, 20190084. [CrossRef]

72. Manach, C.; Scalbert, A.; Morand, C.; Rémésy, C.; Jiménez, L. Polyphenols: Food sources and bioavailability. Am. J. Clin. Nutr. 2004, 79, 727-747. [CrossRef] [PubMed]

73. Suou, K.; Iwabe, T.; Harada, T. Apigenin inhibits tnf-induced cell proliferation in endometriotic stromal cells. Fertil. Steril. 2009, 92, S11. [CrossRef]

74. Suou, K.; Taniguchi, F.; Tagashira, Y.; Kiyama, T.; Terakawa, N.; Harada, T. Apigenin inhibits tumor necrosis factor $\alpha$-induced cell proliferation and prostaglandin E2 synthesis by inactivating NFKB in endometriotic stromal cells. Fertil. Steril. 2011, 95, 1518-1521. [CrossRef]

75. Park, S.; Lim, W.; Bazer, F.W.; Song, G. Apigenin induces ROS-dependent apoptosis and ER stress in human endometriosis cells. J. Cell Physiol. 2018, 233, 3055-3065. [CrossRef] [PubMed]

76. Dean, M.; Austin, J.; Jinhong, R.; Johnson, M.E.; Lantvit, D.D.; Burdette, J.E. The Flavonoid Apigenin Is a Progesterone Receptor Modulator with In Vivo Activity in the Uterus. Horm. Cancer 2018, 9, 265-277. [CrossRef]

77. Sharma, C.; Al Kaabi, J.M.; Nurulain, S.; Goyal, S.; Amjad Kamal, M.; Ojha, S. Polypharmacological Properties and Therapeutic Potential of $\beta$-Caryophyllene: A Dietary Phytocannabinoid of Pharmaceutical Promise. Curr. Pharm. Design. 2016, 22, 3237-3264. [CrossRef]

78. Kim, C.; Cho, S.K.; Kim, K.-D.; Nam, D.; Chung, W.-S.; Jang, H.-J.; Lee, S.-G.; Shim, B.S.; Sethi, G.; Ahn, K.S. $\beta$-Caryophyllene oxide potentiates $\mathrm{TNF} \alpha$-induced apoptosis and inhibits invasion through down-modulation of NF- $\mathrm{kB}$-regulated gene products. Apoptosis 2014, 19, 708-718. [CrossRef]

79. Yang, M.; Lv, Y.; Tian, X.; Lou, J.; An, R.; Zhang, Q.; Li, M.; Xu, L.; Dong, Z. Neuroprotective effect of $\beta$-caryophyllene on cerebral ischemia-reperfusion injury via regulation of necroptotic neuronal death and inflammation: In vivo and in vitro. Front. Neurosci. 2017, 11, 583. [CrossRef] [PubMed]

80. Abbas, M.A.; Taha, M.O.; Zihlif, M.A.; Disi, A.M. $\beta$-Caryophyllene causes regression of endometrial implants in a rat model of endometriosis without affecting fertility. Eur. J. Pharmacol. 2013, 702, 12-19. [CrossRef]

81. Ojha, S.; Javed, H.; Azimullah, S.; Haque, M.E. $\beta$-Caryophyllene, a phytocannabinoid attenuates oxidative stress, neuroinflammation, glial activation, and salvages dopaminergic neurons in a rat model of Parkinson disease. Mol. Cell Biochem. 2016, 418, 59-70. [CrossRef]

82. Anand, P.; Kunnumakkara, A.B.; Newman, R.A.; Aggarwal, B.B. Bioavailability of Curcumin: Problems and Promises. Mol. Pharm. 2007, 4, 807-818. [CrossRef] [PubMed]

83. Zhang, Y.; Cao, H.; Yu, Z.; Peng, H.-Y.; Zhang, C.-J. Curcumin inhibits endometriosis endometrial cells by reducing estradiol production. Iranian J. Reprod. Med. 2013, 11, 415-422.

84. Cao, W.-G.; Morin, M.; Metz, C.; Maheux, R.; Akoum, A. Stimulation of Macrophage Migration Inhibitory Factor Expression in Endometrial Stromal Cells by Interleukin 1, beta Involving the Nuclear Transcription Factor NFkB1. Biol. Reprod. 2005, 73, 565-570. [CrossRef] [PubMed]

85. Xu, S.; Yang, Z.; Fan, Y.; Guan, B.; Jia, J.; Gao, Y.; Wang, K.; Wu, K.; Wang, X.; Zheng, P. Curcumin enhances temsirolimus-induced apoptosis in human renal carcinoma cells through upregulation of YAP/p53. Oncol. Lett. 2016, 12, 4999-5006. [CrossRef] [PubMed]

86. Ali, B.H.; Al-Salam, S.; Al Suleimani, Y.; Al Kalbani, J.; Al Bahlani, S.; Ashique, M.; Manoj, P.; Al Dhahli, B.; Al Abri, N.; Naser, H.T.; et al. Curcumin Ameliorates Kidney Function and Oxidative Stress in Experimental Chronic Kidney Disease. Basic Clin. Pharmacol. Toxicol. 2018, 122, 65-73. [CrossRef]

87. Zhang, Y.; Cao, H.; Hu, Y.-Y.; Wang, H.; Zhang, C.-J. Inhibitory effect of curcumin on angiogenesis in ectopic endometrium of rats with experimental endometriosis. Int. J. Mol. Med. 2011, 27, 87-94. [CrossRef]

88. Lee, A.Y.-L.; Fan, C.-C.; Chen, Y.-A.; Cheng, C.-W.; Sung, Y.-J.; Hsu, C.-P.; Kao, T.-Y. Curcumin Inhibits Invasiveness and Epithelial-Mesenchymal Transition in Oral Squamous Cell Carcinoma Through Reducing Matrix Metalloproteinase 2, 9 and Modulating p53-E-Cadherin Pathway. Integr. Cancer Ther. 2015, 14, 484-490. [CrossRef]

89. Chen, Q.; Gao, Q.; Chen, K.; Wang, Y.; Chen, L.; Li, X. Curcumin suppresses migration and invasion of human endometrial carcinoma cells. Oncol. Lett. 2015, 10, 1297-1302. [CrossRef]

90. Ahn, W.S.; Huh, S.W.; Bae, S.M.; Lee, I.P.; Lee, J.M.; Namkoong, S.E.; Kim, C.K.; Sin, J.I. A major constituent of green tea, EGCG, inhibits the growth of a human cervical cancer cell line, CaSki cells, through apoptosis, G(1) arrest, and regulation of gene expression. DNA Cell Biol. 2003, 22, 217-224. [CrossRef]

91. Xu, H.; Becker, C.M.; Lui, W.T.; Chu, C.Y.; Davis, T.N.; Kung, A.L.; Birsner, A.E.; D’Amato, R.J.; Wai Man, G.C.; Wang, C.C. Green tea epigallocatechin-3-gallate inhibits angiogenesis and suppresses vascular endothelial growth factor C/vascular endothelial growth factor receptor 2 expression and signaling in experimental endometriosis in vivo. Fertil. Steril. 2011, 96, 1021-1028.e1021. [CrossRef] 
92. Matsuzaki, S.; Darcha, C. Antifibrotic properties of epigallocatechin-3-gallate in endometriosis. Hum. Reprod. 2014, 29 , 1677-1687. [CrossRef] [PubMed]

93. Chan, T.-H.; Wang, C.-C. Prodrug of Green Tea Epigallocatechin-3-Gallate (Pro-EGCG) for Use in the Treatment of Endometriosis. U.S. Patent No. 9,713,603, 25 July 2017.

94. Uchiyama, Y.; Suzuki, T.; Mochizuki, K.; Goda, T. Dietary Supplementation with (-)-Epigallocatechin-3-gallate Reduces Inflammatory Response in Adipose Tissue of Non-obese Type 2 Diabetic Goto-Kakizaki (GK) Rats. J. Agric. Food Chem. 2013, 61, 11410-11417. [CrossRef]

95. Zhang, S.; Liu, X.; Mei, L.; Wang, H.; Fang, F. Epigallocatechin-3-gallate (EGCG) inhibits imiquimod-induced psoriasis-like inflammation of BALB/c mice. BMC Complement. Altern. Med. 2016, 16, 1-11. [CrossRef] [PubMed]

96. Huang, C.-Y.; Han, Z.; Li, X.; Xie, H.-H.; Zhu, S.-S. Mechanism of EGCG promoting apoptosis of MCF-7 cell line in human breast cancer. Oncol. letters. 2017, 14, 3623-3627. [CrossRef]

97. Chen, S.J.; Yao, X.D.; Peng, B.; Xu, Y.F.; Wang, G.C.; Huang, J.; Liu, M.; Zheng, J.H. Epigallocatechin-3-gallate inhibits migration and invasion of human renal carcinoma cells by downregulating matrix metalloproteinase-2 and matrix metalloproteinase-9. Experimental Ther. Med. 2016, 11, 1243-1248. [CrossRef] [PubMed]

98. Yavuz, E.; Oktem, M.; Esinler, I.; Toru, S.A.; Zeyneloglu, H.B. Genistein causes regression of endometriotic implants in the rat model. Fertil. Steril. 2007, 88, 1129-1134. [CrossRef]

99. Yu, X.; Zhu, J.; Mi, M.; Chen, W.; Pan, Q.; Wei, M.J. Anti-angiogenic genistein inhibits VEGF-induced endothelial cell activation by decreasing PTK activity and MAPK activation. Med. Oncol. 2012, 29, 349-357. [CrossRef]

100. Wei, D.; Yang, L.; Lv, B.; Chen, L. Genistein suppresses retinoblastoma cell viability and growth and induces apoptosis by upregulating miR-145 and inhibiting its target ABCE1. Mol. Vis. 2017, 23, 385-394.

101. Surico, D.; Ercoli, A.; Farruggio, S.; Raina, G.; Filippini, D.; Mary, D.; Minisini, R.; Surico, N.; Pirisi, M.; Grossini, E. Modulation of Oxidative Stress by 17 ß-Estradiol and Genistein in Human Hepatic Cell Lines In Vitro. Cell Phys. Biochem. 2017, 42, 1051-1062. [CrossRef]

102. Geng, Y.; Zhu, S.; Cheng, P.; Lu, Z.-M.; Xu, H.-Y.; Shi, J.-S.; Xu, Z.-H. Bioassay-guided fractionation of ethyl acetate extract from Armillaria mellea attenuates inflammatory response in lipopolysaccharide (LPS) stimulated BV-2 microglia. Phytomedicine 2017, 26, 55-61. [CrossRef]

103. Cotroneo, M.S.; Lamartiniere, C.A. Pharmacologic, but Not Dietary, Genistein Supports Endometriosis in a Rat Model. Toxic Sci. 2001, 61, 68-75. [CrossRef]

104. Lopez-Lazaro, M. Distribution and Biological Activities of the Flavonoid Luteolin. Mini Rev. Med. Chem. 2009, 9, 31-59. [CrossRef]

105. Park, S.; Lim, W.; You, S.; Song, G. Ameliorative effects of luteolin against endometriosis progression in vitro and in vivo. J. Nutr. Biochem. 2019, 67, 161-172. [CrossRef]

106. Nordeen, S.K.; Bona, B.J.; Jones, D.N.; Lambert, J.R.; Jackson, T.A. Endocrine disrupting activities of the flavonoid nutraceuticals luteolin and quercetin. Homones Cancer. 2013, 4, 293-300. [CrossRef]

107. Moga, M.A.; Dimienescu, O.G.; Arvatescu, C.A.; Mironescu, A.; Dracea, L.; Ples, L. The Role of Natural Polyphenols in the Prevention and Treatment of Cervical Cancer-An Overview. Molecules 2016, 21, 1055. [CrossRef] [PubMed]

108. Ryu, S.; Bazer, F.W.; Lim, W.; Song, G. Chrysin leads to cell death in endometriosis by regulation of endoplasmic reticulum stress and cytosolic calcium level. J. Cell Physiol. 2019, 234, 2480-2490. [CrossRef]

109. Yao, Z.; Li, C.; Gu, Y.; Zhang, Q.; Liu, L.; Meng, G.; Wu, H.; Bao, X.; Zhang, S.; Sun, S.; et al. Dietary myricetin intake is inversely associated with the prevalence of type 2 diabetes mellitus in a Chinese population. Nutr. Res. 2019, 68, 82-91. [CrossRef] [PubMed]

110. Park, S.; Song, G.; Lim, W. Myricetin inhibits endometriosis growth through cyclin E1 down-regulation in vitro and in vivo. J. Nutr. Biochem. 2020, 78, 108328. [CrossRef] [PubMed]

111. Kanno, S.; Tomizawa, A.; Ohtake, T.; Koiwai, K.; Ujibe, M.; Ishikawa, M. Naringenin-induced apoptosis via activation of NF-kappaB and necrosis involving the loss of ATP in human promyeloleukemia HL-60 cells. Toxicol. Lett. 2006, 166, 131-139. [CrossRef]

112. Ratnam, D.V.; Ankola, D.D.; Bhardwaj, V.; Sahana, D.K.; Kumar, M.N.V.R. Role of antioxidants in prophylaxis and therapy: A pharmaceutical perspective. J. Control. Release 2006, 113, 189-207. [CrossRef]

113. Park, S.; Lim, W.; Bazer, F.W.; Song, G. Naringenin induces mitochondria-mediated apoptosis and endoplasmic reticulum stress by regulating MAPK and AKT signal transduction pathways in endometriosis cells. Mol. Hum. Reprod. 2017, 23, 842-854. [CrossRef]

114. Kapoor, R.; Sirohi, V.K.; Gupta, K.; Dwivedi, A. Naringenin ameliorates progression of endometriosis by modulating Nrf2/Keap1/HO1 axis and inducing apoptosis in rats. J. Nutr. Biochem. 2019, 70, 215-226. [CrossRef] [PubMed]

115. Chen, Y.; Chen, C.; Shi, S.; Han, J.; Wang, J.; Hu, J.; Liu, Y.; Cai, Z.; Yu, C. Endometriotic Implants Regress in Rat Models Treated With Puerarin by Decreasing Estradiol Level. Reprod. Sci. 2011, 18, 886-891. [CrossRef]

116. Wang, D.; Liu, Y.; Han, J.; Zai, D.; Ji, M.; Cheng, W.; Xu, L.; Yang, L.; He, M.; Ni, J. Puerarin suppresses invasion and vascularization of endometriosis tissue stimulated by $17 \beta$-estradiol. PLoS ONE 2011, 6, e25011. [CrossRef] [PubMed]

117. Cheng, W.; Chen, L.; Yang, S.; Han, J.; Zhai, D.; Ni, J.; Yu, C.; Cai, Z. Puerarin Suppresses Proliferation of Endometriotic Stromal Cells Partly via the MAPK Signaling Pathway Induced by 17ß-estradiol-BSA. PLoS ONE 2012, 7, e45529. [CrossRef] [PubMed]

118. Murahari, M.; Singh, V.; Chaubey, P.; Suvarna, V. A Critical Review on Anticancer Mechanisms of Natural Flavonoid Puerarin. Anti-Cancer Agents Med. Chem. 2020, 20, 678-686. [CrossRef] [PubMed] 
119. Lehtonen, H.M.; Lehtinen, O.; Suomela, J.P.; Viitanen, M.; Kallio, H. Flavonol glycosides of sea buckthorn (Hippophaë rhamnoides ssp. sinensis) and lingonberry (Vaccinium vitis-idaea) are bioavailable in humans and monoglucuronidated for excretion. J. Agric. Food Chem. 2010, 58, 620-627. [CrossRef]

120. Scambia, G.; Ranelletti, F.O.; Panici, P.B.; Piantelli, M.; Bonanno, G.; De Vincenzo, R.; Ferrandina, G.; Maggiano, N.; Capelli, A.; Mancuso, S. Inhibitory effect of quercetin on primary ovarian and endometrial cancers and synergistic activity with cisdiamminedichloroplatinum(II). Gynecol. Oncol. 1992, 45, 13-19. [CrossRef]

121. Zhang, X.; Wang, X.; Wang, H.-J.; Yang, Q.; Qie, M.-R. Inhibition effect and mechanisms of quercetin on surgically induced endometriosis. J. Sichuan Univ. 2009, 40, 228-231, 244.

122. Cao, Y.; Zhuang, M.-F.; Yang, Y.; Xie, S.-W.; Cui, J.-G.; Cao, L.; Zhang, T.-T.; Zhu, Y. Preliminary Study of Quercetin Affecting the Hypothalamic-Pituitary-Gonadal Axis on Rat Endometriosis Model. Evid. Complement. Altern. Med. 2014, $2014,781684$. [CrossRef]

123. Rauf, A.; Imran, M.; Butt, M.S.; Nadeem, M.; Peters, D.G.; Mubarak, M.S. Resveratrol as an anti-cancer agent: A review. Crit Rev. Food Sci. Nutr. 2018, 58, 1428-1447. [CrossRef]

124. Chu, M.; Almagro, L.; Chen, B.; Burgos, L.; Pedreño, M.A. Recent trends and comprehensive appraisal for the biotechnological production of trans-resveratrol and its derivatives. Phytochem. Rev. 2018, 17, 491-508. [CrossRef]

125. Nakata, R.; Takahashi, S.; Inoue, H. Recent advances in the study on resveratrol. Biol. Pharm. Bull. 2012, 35, 273-279. [CrossRef]

126. Jang, M.; Cai, L.; Udeani, G.O.; Slowing, K.V.; Thomas, C.F.; Beecher, C.W.W.; Fong, H.H.S.; Farnsworth, N.R.; Kinghorn, A.D.; Mehta, R.G.; et al. Cancer Chemopreventive Activity of Resveratrol, a Natural Product Derived from Grapes. Science 1997, 275, 218-220. [CrossRef]

127. Chu, H.; Li, H.; Guan, X.; Yan, H.; Zhang, X.; Cui, X.; Li, X.; Cheng, M. Resveratrol protects late endothelial progenitor cells from TNF- $\alpha$-induced inflammatory damage by upregulating Krüppel-like factor-2. Mol. Med. Rep. 2018, 17, 5708-5715. [CrossRef] [PubMed]

128. Shakibaei, M.; Buhrmann, C.; Mobasheri, A. Resveratrol-mediated SIRT-1 interactions with p300 modulate receptor activator of NF-kappaB ligand (RANKL) activation of NF-kappaB signaling and inhibit osteoclastogenesis in bone-derived cells. J. Biol. Chem. 2011, 286, 11492-11505. [CrossRef] [PubMed]

129. Trapp, V.; Parmakhtiar, B.; Papazian, V.; Willmott, L.; Fruehauf, J.P. Anti-angiogenic effects of resveratrol mediated by decreased VEGF and increased TSP1 expression in melanoma-endothelial cell co-culture. Angiogenesis 2010, 13, 305-315. [CrossRef]

130. Polak, G.; Mazurek, D.; Rogala, E.; Nowicka, A.; Derewianka-Polak, M.; Kotarski, J. Increased oxidized LDL cholesterol levels in peritoneal fluid of women with advanced-stage endometriosis. Ginekol Pol. 2011, 82, 191-194. [PubMed]

131. Truong, V.-L.; Jun, M.; Jeong, W.-S. Role of resveratrol in regulation of cellular defense systems against oxidative stress. Biofactors 2018, 44, 36-49. [CrossRef] [PubMed]

132. Yadav, A.; Sunkaria, A.; Singhal, N.; Sandhir, R. Resveratrol loaded solid lipid nanoparticles attenuate mitochondrial oxidative stress in vascular dementia by activating Nrf2/HO-1 pathway. Neurochem. Int. 2018, 112, 239-254. [CrossRef]

133. Liu, M.; Hansen, P.E.; Wang, G.; Qiu, L.; Dong, J.; Yin, H.; Qian, Z.; Yang, M.; Miao, J. Pharmacological profile of xanthohumol, a prenylated flavonoid from hops (Humulus lupulus). Molecules 2015, 20, 754-779. [CrossRef]

134. Rudzitis-Auth, J.; Körbel, C.; Scheuer, C.; Menger, M.D.; Laschke, M.W. Xanthohumol inhibits growth and vascularization of developing endometriotic lesions. Hum. Reprod. 2012, 27, 1735-1744. [CrossRef]

135. Dell'Eva, R.; Ambrosini, C.; Vannini, N.; Piaggio, G.; Albini, A.; Ferrari, N. AKT/NF-kB inhibitor xanthohumol targets cell growth and angiogenesis in hematologic malignancies. Cancer. 2007, 110, 2007-2011. [CrossRef]

136. Dorn, C.; Massinger, S.; Wuzik, A.; Heilmann, J.; Hellerbrand, C. Xanthohumol suppresses inflammatory response to warm ischemia-reperfusion induced liver injury. Exper Mol. Pathol. 2013, 94, 10-16. [CrossRef]

137. Jin, M.; Zhao, K.; Huang, Q.; Xu, C.; Shang, P. Isolation, structure and bioactivities of the polysaccharides from Angelica sinensis (Oliv.) Diels: A review. Carbohydr. Polym. 2012, 89, 713-722. [CrossRef] [PubMed]

138. Chao, W.-W.; Lin, B.-F. Bioactivities of major constituents isolated from Angelica sinensis (Danggui). Chinese Med. 2011,6 , 29. [CrossRef]

139. Liu, C.; Li, J.; Meng, F.Y.; Liang, S.X.; Deng, R.; Li, C.K.; Pong, N.H.; Lau, C.P.; Cheng, S.W.; Ye, J.Y.; et al. Polysaccharides from the root of Angelica sinensis promotes hematopoiesis and thrombopoiesis through the PI3K/AKT pathway. BMC Complement. Alternat Med. 2010, 10, 79. [CrossRef]

140. Xiong, Q.-X.; Ruan, X.-Y.; Deng, A.-P.; Liu, J.; Zhou, Q. Anti-endometriotic effect of Angelica sinensis (Oliv.) Diels extract in human endometriotic cells and rats. Trop. J. Pharm. Res. 2020, 19, 817-821. [CrossRef]

141. Yeşilada, E.; Honda, G.; Sezik, E.; Tabata, M.; Fujita, T.; Tanaka, T.; Takeda, Y.; Takaishi, Y. Traditional medicine in Turkey. V. Folk medicine in the inner Taurus Mountains. J. Ethnopharmacol. 1995, 46, 133-152. [CrossRef]

142. Dall'Acqua, S.; Bolego, C.; Cignarella, A.; Gaion, R.M.; Innocenti, G. Vasoprotective activity of standardized Achillea millefolium extract. Phytomedicine 2011, 18, 1031-1036. [CrossRef]

143. Demirel, M.A.; Suntar, I.; Ilhan, M.; Keles, H.; Kupeli Akkol, E. Experimental endometriosis remission in rats treated with Achillea biebersteinii Afan.: Histopathological evaluation and determination of cytokine levels. Eur. J. Obstet. Gynecol. Reprod. Biol. 2014, 175, 172-177. [CrossRef] [PubMed] 
144. Mazandarani, M.; Osia, N.; Ghafourian, M. Antioxidant activity and ethno pharmacological survey of Achillea biebersteinii Afan. in the treatment of dysmenorrhoea in traditional medicine of Golestan province, Iran. J. Women Health Reprod. Sci. 2015, 3, 107-110. [CrossRef]

145. Jaffal, S.M.; Abbas, M.A. Antinociceptive action of Achillea biebersteinii methanolic flower extract is mediated by interaction with cholinergic receptor in mouse pain models. Inflammopharmacology 2019, 27, 961-968. [CrossRef]

146. Umano, K.; Hagi, Y.; Nakahara, K.; Shoji, A.; Shibamoto, T. Volatile Chemicals Identified in Extracts from Leaves of Japanese Mugwort (Artemisia princeps Pamp.). J. Agric. Food Chem. 2000, 48, 3463-3469. [CrossRef] [PubMed]

147. Kim, J.-H.; Jung, S.-H.; Yang, Y.-I.; Ahn, J.-H.; Cho, J.-G.; Lee, K.-T.; Baek, N.-I.; Choi, J.-H. Artemisia leaf extract induces apoptosis in human endometriotic cells through regulation of the p38 and NFKB pathways. J. Ethnopharmacol. 2013, 145, 767-775. [CrossRef]

148. Cho, J.-H.; Lee, J.-G.; Yang, Y.-I.; Kim, J.-H.; Ahn, J.-H.; Baek, N.-I.; Lee, K.-T.; Choi, J.-H. Eupatilin, a dietary flavonoid, induces G2/M cell cycle arrest in human endometrial cancer cells. Food Chem. Toxicol. 2011, 49, 1737-1744. [CrossRef]

149. Han, J.-M.; Kim, M.-J.; Baek, S.-H.; An, S.; Jin, Y.-Y.; Chung, H.-G.; Baek, N.-I.; Choi, M.-S.; Lee, K.-T.; Jeong, T.-S. Antiatherosclerotic Effects of Artemisia princeps Pampanini cv. Sajabal in LDL Receptor Deficient Mice. J. Agric. Food Chem. 2009, 57, 1267-1274. [CrossRef]

150. Kim, M.-J.; Han, J.-M.; Jin, Y.-Y.; Baek, N.-I.; Bang, M.-H.; Chung, H.-G.; Choi, M.-S.; Lee, K.-T.; Sok, D.-E.; Jeong, T.-S. In Vitro antioxidant and anti-inflammatory activities of Jaceosidin from Artemisia princeps Pampanini cv. Sajabal. Arch Pharm. Res. 2008, 31, 429-437. [CrossRef] [PubMed]

151. Kim, K.-H.; Park, J.K.; Choi, Y.-W.; Kim, Y.-H.; Lee, E.N.; Lee, J.-R.; Kim, H.-S.; Baek, S.-Y.; Kim, B.-S.; Lee, K.-S. Hexane extract of aged black garlic reduces cell proliferation and attenuates the expression of ICAM-1 and VCAM-1 in TNF- $\alpha$-activated human endometrial stromal cells. Int. J. Mol. Med. 2013, 32, 67-78. [CrossRef]

152. Xiao, D.; Li, M.; Herman-Antosiewicz, A.; Antosiewicz, J.; Xiao, H.; Lew, K.L.; Zeng, Y.; Marynowski, S.W.; Singh, S.V. Diallyl trisulfide inhibits angiogenic features of human umbilical vein endothelial cells by causing Akt inactivation and down-regulation of VEGF and VEGF-R2. Nutr. Cancer 2006, 55, 94-107. [CrossRef]

153. Hodge, G.; Hodge, S.; Han, P. Allium sativum (garlic) suppresses leukocyte inflammatory cytokine production in vitro: Potential therapeutic use in the treatment of inflammatory bowel disease. J. Quant. Cell Sci. 2002, 48, 209-215. [CrossRef] [PubMed]

154. Padiya, R.; Chowdhury, D.; Borkar, R.; Srinivas, R.; Pal Bhadra, M.; Banerjee, S.K. Garlic Attenuates Cardiac Oxidative Stress via Activation of PI3K/AKT/Nrf2-Keap1 Pathway in Fructose-Fed Diabetic Rat. PLoS ONE 2014, 9, e94228. [CrossRef] [PubMed]

155. Avci, A.; Atli, T.; Ergüder, İ.B.; Varli, M.; Devrim, E.; Demir, Ö.; Durak, I.; Turgay, M. Effects of grape consumption on plasma and erythrocyte antioxidant parameters in elderly subjects. Turkish J. Med. Sci. 2010, 40, 525-529. [CrossRef]

156. Kim, Y.-S.; Lim, E.-M.; Cho, H.-J. Effects of Astragalus membranaceus on Surgically Induced Endometriosis in Rats. J. Korean Obstet. Gynecol. 2007, 20, 43-59.

157. Orkhon, B.; Kobayashi, K.; Javzan, B.; Sasaki, K. Astragalus root induces ovarian $\beta$-oxidation and suppresses estrogen-dependent uterine proliferation. Mol. Med. Rep. 2018, 18, 5198-5206. [CrossRef]

158. Zhao, R.-H.; Hao, Z.-P.; Zhang, Y.; Lian, F.-M.; Sun, W.-W.; Liu, Y.; Wang, R.; Long, L.; Cheng, L.; Ding, Y.-F. Controlling the recurrence of pelvic endometriosis after a conservative operation: Comparison between Chinese herbal medicine and western medicine. Chin. J. Integr. Med. 2013, 19, 820-825. [CrossRef]

159. Kong, Y.; Zhang, J.-w. Experimental study on rat model of endometriosis treated with tamoxifen and rhizoma curcumae oil. J. Sichuan Univ 2006, 37, 596-598.

160. Swarnakar, S.; Paul, S. Curcumin arrests endometriosis by downregulation of matrix metalloproteinase-9 activity. Indian J. Biochem. Biophys 2009, 46, 59-65. [PubMed]

161. Uchio, R.; Higashi, Y.; Kohama, Y.; Kawasaki, K.; Hirao, T.; Muroyama, K.; Murosaki, S. A hot water extract of turmeric (Curcuma longa) suppresses acute ethanol-induced liver injury in mice by inhibiting hepatic oxidative stress and inflammatory cytokine production. J. Nutr. Sci. 2017, 6, e3. [CrossRef]

162. Kumar, G.; Tajpara, P.; Maru, G. Dietary Turmeric Post-Treatment Decreases DMBA-Induced Hamster Buccal Pouch Tumor Growth by Altering Cell Proliferation and Apoptosis-Related Markers. J. Environ. Pathol Toxicol. Oncol. 2012, 31, 295-312. [CrossRef] [PubMed]

163. Yuliani, S.; Mustofa; Partadiredja, G. The neuroprotective effects of an ethanolic turmeric (Curcuma longa L.) extract against trimethyltin-induced oxidative stress in rats. Nutr. Neurosci. 2019, 22, 797-804. [CrossRef] [PubMed]

164. Kuo, C.-F.; Chyau, C.-C.; Wang, T.-S.; Li, C.-R.; Hu, T.-J. Enhanced Antioxidant and Anti-inflammatory Activities of Monascus pilosus Fermented Products by Addition of Turmeric to the Medium. J. Agric. Food Chem. 2009, 57, 11397-11405. [CrossRef]

165. Psotová, J.; Kolář, M.; Soušek, J.; Švagera, Z.; Vičar, J.; Ulrichová, J. Biological activities of Prunella vulgaris extract. Phytoter. Res. 2003, 17, 1082-1087. [CrossRef] [PubMed]

166. Collins, N.H.; Lessey, E.C.; DuSell, C.D.; McDonnell, D.P.; Fowler, L.; Palomino, W.A.; Illera, M.J.; Yu, X.; Mo, B.; Houwing, A.M.; et al. Characterization of Antiestrogenic Activity of the Chinese Herb, Prunella vulgaris, Using In Vitro and In Vivo (Mouse Xenograft) Models1. Biol. Reprod. 2009, 80, 375-383. [CrossRef]

167. Yin, D.T.; Lei, M.; Xu, J.; Li, H.; Wang, Y.; Liu, Z.; Ma, R.; Yu, K.; Li, X. The Chinese herb Prunella vulgaris promotes apoptosis in human well-differentiated thyroid carcinoma cells via the B-cell lymphoma-2/Bcl-2-associated X protein/caspase-3 signaling pathway. Oncol. Lett. 2017, 14, 1309-1314. [CrossRef] [PubMed] 
168. Park, S.H.; Koo, H.J.; Sung, Y.Y.; Kim, H.K. The protective effect of Prunella vulgaris ethanol extract against vascular inflammation in TNF- $\alpha$-stimulated human aortic smooth muscle cells. BMB Rep. 2013, 46, 352-357. [CrossRef] [PubMed]

169. Sun, J.; Wei, Y.-H. A new alkaloid-aluminum glycoside isolated from Rhizoma Sparganii (Sparganium stoloniferum Buch.-Ham.). J. Med. Plants Res. 2011, 5, 3128-3131. [CrossRef]

170. Sun, J.; Wang, S.; Wei, Y.-H. Reproductive toxicity of Rhizoma Sparganii (Sparganium stoloniferum Buch.-Ham.) in mice: Mechanisms of anti-angiogenesis and anti-estrogen pharmacologic activities. J. Ethnopharmacol. 2011, 137, 1498-1503. [CrossRef]

171. Wu, Y.-z.; Sun, J.; Wang, Y.-b. Selective estrogen receptor modulator: A novel polysaccharide from Sparganii Rhizoma induces apoptosis in breast cancer cells. Carbohydr. Polym. 2017, 163, 199-207. [CrossRef]

172. Jiang, Y.-Y.; Li, Y.-B.; Yu, J.; Chen, H.; Zhou, J.; Wang, L.; Zhang, L.; Zhao, M.-J.; Zhou, Y.-H.; Yu, L. Preliminary structure and bioactivities of polysaccharide SMWP-U\&E isolated from Salvia miltiorrhiza Bunge Residue. Int. j Biol. Mol. 2020, 157, 434-443. [CrossRef]

173. Wang, B.Q. Salvia miltiorrhiza chemical and pharmacological review of a medicinal plant. J. Med. Plants Res. 2010, 4, 2813-2820.

174. Chen, Z.-z.; Gong, X. Tanshinone IIA contributes to the pathogenesis of endometriosis via renin angiotensin system by regulating the dorsal root ganglion axon sprouting. Life Sci. 2020, 240, 117085. [CrossRef]

175. Liu, J.-J.; Lin, D.-J.; Liu, P.-Q.; Huang, M.; Li, X.-D.; Huang, R.-W. Induction of apoptosis and inhibition of cell adhesive and invasive effects by tanshinone IIA in acute promyelocytic leukemia cells in vitro. J. Biomed. Sci. 2006, 13, 813-823. [CrossRef]

176. Tsai, M.-Y.; Yang, R.-C.; Wu, H.-T.; Pang, J.-H.S.; Huang, S.-T. Anti-angiogenic effect of Tanshinone IIA involves inhibition of matrix invasion and modification of MMP-2/TIMP-2 secretion in vascular endothelial cells. Cancer Lett. 2011, 310, 198-206. [CrossRef]

177. Kim, S.Y.; Moon, T.C.; Chang, H.W.; Son, K.H.; Kang, S.S.; Kim, H.P. Effects of tanshinone I isolated from Salvia miltiorrhiza Bunge on arachidonic acid metabolism and in vivo inflammatory responses. Phytoter. Res. 2002, 16, 616-620. [CrossRef]

178. Zhou, Z.-H.; Weng, Q.; Zhou, J.-H.; Zhou, J. Extracts of Salvia miltiorrhiza bunge on the cytokines of rat endometriosis models. Afr. J. Trad. Complement. Altern. Med. 2012, 9, 303-314. [CrossRef]

179. Tu, Q.; Wang, R.; Ding, B.; Zhong, W.; Cao, H. Protective and antioxidant effect of Danshen polysaccharides on cerebral ischemia/reperfusion injury in rats. Int. J. Biol. Macromol. 2013, 60, 268-271. [CrossRef] [PubMed]

180. Qian, Q.; Qian, S.; Fan, P.; Huo, D.; Wang, S. Effect of Salvia miltiorrhiza Hydrophilic Extract on Antioxidant Enzymes in Diabetic Patients with Chronic Heart Disease: A Randomized Controlled Trial. Phytoter. Res. 2012, 26, 60-66. [CrossRef] [PubMed]

181. He, D.-Y.; Dai, S.-M. Anti-inflammatory and immunomodulatory effects of Paeonia lactiflora Pall., a traditional Chinese herbal medicine. Front. Pharmacol. 2011, 2, 10. [CrossRef] [PubMed]

182. Fan, Y.-X.; Hu, L.; Zhu, S.-H.; Han, Y.; Liu, W.-T.; Yang, Y.-J.; Li, Q.-P. Paeoniflorin attenuates postoperative pain by suppressing Matrix Metalloproteinase-9/2 in mice. Eur. J. Pain. 2018, 22, 272-281. [CrossRef]

183. Zhang, J.; Wang, F.; Wang, H.; Wang, Y.; Wu, Y.; Xu, H.; Su, C. Paeoniflorin inhibits proliferation of endometrial cancer cells via activating MAPK and NF-кB signaling pathways. Experim Ther. Med. 2017, 14, 5445-5451. [CrossRef] [PubMed]

184. Huang, Y.; Ohno, O.; Suenaga, K.; Miyamoto, K. Apoptosis-inducing activity and antiproliferative effect of Paeoniflorigenone from moutan cortex. Biosci. Biotechnol. Biochem. 2017, 81, 1106-1113. [CrossRef]

185. Rop, O.; Reznicek, V.; Valsikova, M.; Jurikova, T.; Mlcek, J.; Kramarova, D. Antioxidant properties of European cranberrybush fruit (Viburnum opulus var. edule). Molecules 2010, 15, 4467-4477. [CrossRef] [PubMed]

186. Moldovan, B.; David, L.; Vulcu, A.; Olenic, L.; Perde-Schrepler, M.; Fischer-Fodor, E.; Baldea, I.; Clichici, S.; Filip, G.A. In vitro and in vivo anti-inflammatory properties of green synthesized silver nanoparticles using Viburnum opulus L. fruits extract. Mater. Sci. Engin. 2017, 79, 720-727. [CrossRef] [PubMed]

187. Saltan, G.; Süntar, I.; Ozbilgin, S.; Ilhan, M.; Demirel, M.A.; Oz, B.E.; Keleş, H.; Akkol, E.K. Viburnum opulus L.: A remedy for the treatment of endometriosis demonstrated by rat model of surgically-induced endometriosis. J. Ethnopharmacol. 2016, 193, 450-455. [CrossRef]

188. Zayachkivska, O.; Gzhegotsky, M.; Terletska, O.; Lutsyk, D.; Yaschenko, A.; Dzhura, O. Influence of Viburnum opulus proanthocyanidins on stress-induced gastrointestinal mucosal damage. J. Physiol. Pharmacol. 2006, 57, 155.

189. Nagulendran, K.; Velavan, S.; Mahesh, R.; Begum, V.H. In vitro antioxidant activity and total polyphenolic content of Cyperus rotundus rhizomes. J. Chem. 2007, 4, 440-449.

190. Ahn, J.-H.; Lee, T.-W.; Kim, K.-H.; Byun, H.; Ryu, B.; Lee, K.-T.; Jang, D.S.; Choi, J.-H. 6-Acetoxy Cyperene, a Patchoulane-type Sesquiterpene Isolated from Cyperus rotundus Rhizomes Induces Caspase-dependent Apoptosis in Human Ovarian Cancer Cells. Phytother Res. 2015, 29, 1330-1338. [CrossRef]

191. Sabbe, S.; Verbeke, W.; Deliza, R.; Matta, V.M.; Van Damme, P. Consumer Liking of Fruit Juices with Different Açaí (Euterpe oleracea Mart.) Concentrations. Food Sci. 2009, 74, S171-S176. [CrossRef]

192. Machado, D.E.; Rodrigues-Baptista, K.C.; Alessandra-Perini, J.; Soares de Moura, R.; Santos, T.A.d.; Pereira, K.G.; Marinho da Silva, Y.; Souza, P.J.C.; Nasciutti, L.E.; Perini, J.A. Euterpe oleracea Extract (Açaí) Is a Promising Novel Pharmacological Therapeutic Treatment for Experimental Endometriosis. PLoS ONE 2016, 11, e0166059. [CrossRef]

193. Del Pozo-Insfran, D.; Percival, S.S.; Talcott, S.T. Açai (Euterpe oleracea Mart.) Polyphenolics in Their Glycoside and Aglycone Forms Induce Apoptosis of HL-60 Leukemia Cells. J. Agric. Food Chem. 2006, 54, 1222-1229. [CrossRef] [PubMed] 
194. Xie, C.; Kang, J.; Li, Z.; Schauss, A.G.; Badger, T.M.; Nagarajan, S.; Wu, T.; Wu, X. The açaí flavonoid velutin is a potent anti-inflammatory agent: Blockade of LPS-mediated TNF- $\alpha$ and IL- 6 production through inhibiting NF- $\mathrm{KB}$ activation and MAPK pathway. J. Nutr. Biochem. 2012, 23, 1184-1191. [CrossRef]

195. Zhou, J.; Zhang, J.; Wang, C.; Qu, S.; Zhu, Y.; Yang, Z.; Wang, L. Açaí (Euterpe oleracea Mart.) attenuates alcohol-induced liver injury in rats by alleviating oxidative stress and inflammatory response. Exp. Ther. Med. 2018, 15, 166-172. [CrossRef]

196. Iravani, S.; Zolfaghari, B. Pharmaceutical and nutraceutical effects of Pinus pinaster bark extract. Res. Pharm. Sci. 2011, 6, 1-11.

197. Maia Junior, H.; Haddad, C.; Casoy, J. Combining oral contraceptives with a natural nuclear factor-kappa B inhibitor for the treatment of endometriosis-related pain. Int. J. Women's Health 2013, 6, 35-39. [CrossRef]

198. Kohama, T.; Herai, K.; Inoue, M. Effect of French maritime pine bark extract on endometriosis as compared with leuprorelin acetate. J. Reprod. Med. Chicago 2007, 52, 703.

199. Yang, I.-H.; Shin, J.-A.; Cho, S.-D. Pycnogenol Induces Nuclear Translocation of Apoptosis-inducing Factor and Caspaseindependent Apoptosis in MC-3 Human Mucoepidermoid Carcinoma Cell Line. J. Cancer Prev. 2014, 19, 265-272. [CrossRef] [PubMed]

200. Zhang, T.; Cong, H.; Zhao, S.; Zhang, Q.; Gu, X. Jing Tong Yu Shu, a traditional Chinese medicine, suppresses IL-1 $\beta$ and IL-6 gene expressions in macrophages, and alleviates endometriosis. Trop. J. Pharm. Res. 2017, 16, 2953-2958. [CrossRef]

201. Ilhan, M.; Ali, Z.; Khan, I.A.; Taştan, H.; Küpeli Akkol, E. Bioactivity-guided isolation of flavonoids from Urtica dioica L. and their effect on endometriosis rat model. J. Ethnopharmacol. 2019, 243, 112100. [CrossRef] [PubMed]

202. Masuda, Y.; Kikuzaki, H.; Hisamoto, M.; Nakatani, N. Antioxidant properties of gingerol related compounds from ginger. Biofactors 2004, 21, 293-296. [CrossRef] [PubMed]

203. Wang, D.; Jiang, Y.; Yang, X.; Wei, Q.; Wang, H. 6-Shogaol reduces progression of experimental endometriosis in vivo and in vitro via regulation of VGEF and inhibition of COX-2 and PGE2-mediated inflammatory responses. Korean J. Physiol. Pharmacol. 2018, 22, 627-636. [CrossRef] [PubMed] 